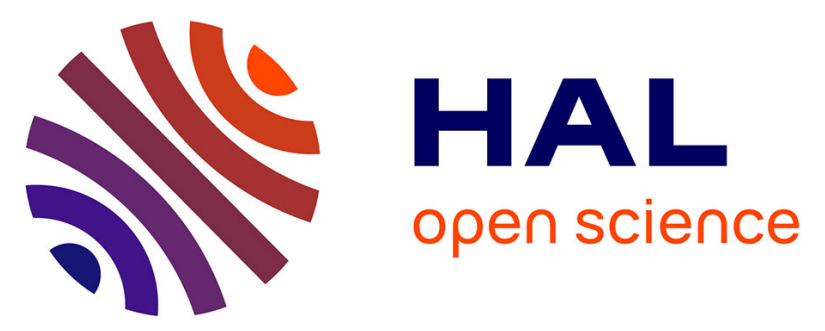

\title{
Combined effect of high light and high salinity on the regulation of photosynthesis in three diatom species belonging to the main growth forms of intertidal flat inhabiting microphytobenthos
}

Philippe Juneau, Alexandre Barnett, Vona Méléder, Christine Dupuy, Johann

Lavaud

\section{To cite this version:}

Philippe Juneau, Alexandre Barnett, Vona Méléder, Christine Dupuy, Johann Lavaud. Combined effect of high light and high salinity on the regulation of photosynthesis in three diatom species belonging to the main growth forms of intertidal flat inhabiting microphytobenthos. Journal of Experimental Marine Biology and Ecology, 2015, 463, pp.95-104. 10.1016/j.jembe.2014.11.003 . hal-01095784

\author{
HAL Id: hal-01095784 \\ https://hal.science/hal-01095784
}

Submitted on 16 Dec 2014

HAL is a multi-disciplinary open access archive for the deposit and dissemination of scientific research documents, whether they are published or not. The documents may come from teaching and research institutions in France or abroad, or from public or private research centers.
L'archive ouverte pluridisciplinaire HAL, est destinée au dépôt et à la diffusion de documents scientifiques de niveau recherche, publiés ou non, émanant des établissements d'enseignement et de recherche français ou étrangers, des laboratoires publics ou privés. 
1 Combined effect of high light and high salinity on the regulation of photosynthesis in three

2 diatom species belonging to the main growth forms of intertidal flat inhabiting

3 microphytobenthos

4

5 Philippe Juneau $^{1 *}$, Alexandre Barnett ${ }^{2}$, Vona Méléder ${ }^{3}$, Christine Dupuy $^{2}$ and Johann Lavaud ${ }^{2}$

6

71 Université du Québec à Montréal, Department of Biological Sciences-TOXEN,

8 Ecotoxicology of Aquatic Microorganisms Laboratory, C.P. 8888, Succ. Centre-Ville,

9 Montréal, Québec, H3C 3P8, Canada

$10{ }^{2}$ UMR7266 LIENSs 'Littoral, Environnement et Sociétés', CNRS/University of La Rochelle, 11 Institute for Coastal and Environmental Research (ILE), 2 rue Olympe de Gouges, 17000 La

12 Rochelle, France.

$13{ }^{3}$ UPRES EA 2160 MMS 'Mer, Molécules, Santé', Université de Nantes, Faculté des Sciences 14 et Techniques, 2 rue de la Houssinière, BP 92208, 44322 Nantes cedex 3, France.

$17 *$ Corresponding author: P. Juneau

18 Université du Québec à Montréal, Department of Biological Sciences-TOXEN, Ecotoxicology 19 of Aquatic Microorganisms Laboratory, C.P. 8888, Succ. Centre-Ville, Montréal, Québec, 20 H3C 3P8, Canada.

21 Phone : 0015149873000\#3988; Fax : 0015149874647; E-mail : juneau.philippe@uqam.ca 


\section{Abstract}

23 The strong biological production of estuarine intertidal flats is mainly supported by benthic

24 diatoms in temperate areas. Their photosynthetic productivity is largely driven by changes in 25 light intensity and temperature at the surface of sediment flats during emersion. The impact of 26 an increase in salinity of the upper-layer sediment pore-water during emersion, which is often 27 coupled with high light (HL), has been less studied. Furthermore, benthic diatoms show 28 several growth forms which inhabit specific sediment types where the pore-water salinity can 29 differentially vary due to the degree of cohesion of sediment grains. So far, no study explored 30 if the main growth forms of benthic diatoms (i.e. epipelon, epipsammon and tychoplankton) 31 show different photophysiological response to a combine high salinity-HL stress. Based on 32 field monitoring, we compared the photophysiology (photosynthetic efficiency and 33 photoprotection) of three representatives of the main growth forms during a short high salinity 34 coupled with a moderate HL stress and stable optimal temperature, i.e. experimental conditions 35 reproducing Spring environmental conditions in intertidal flats by the Atlantic French coast. 36 Our results show that all growth forms reacted to HL exposure alone, as expected. While the 37 epipelon representative was relatively insensitive to high salinity alone and combined with HL, 38 the tychoplankton representative was highly sensitive to both, and the epipsammon 39 representative was sensitive mainly to the stress combination. These specific responses fitted 40 well with i) their natural habitat (i.e. more or less cohesive sediment) for which light climate 41 and changes in salinity are different, ii) their growth form (i.e. motile, immotile or amphibious)

42 which determines their probability to be confronted to a combined high salinity-HL stress. 43 Hence, the negative effect of high salinity on photosynthetic efficiency of benthic diatoms 
44 appears to be mostly restricted to epipsammon and tychoplankton, and in field conditions, its 45 effect probably remains negligible compared to HL stress.

46

47 Keywords: diatom / intertidal flat / microphytobenthos / photoprotection / photosynthesis / 48 salinity.

49

50 List of abbreviations: Chl $a$, chlorophyll $a$; DD, diadinoxathin; DES, de-epoxidation state of 51 diadinoxanthin to diatoxanthin; DT, diatoxanthin; E, light intensity; ETR, electron transport 52 rate; HL, high light; LL, low light; MPB, microphytobenthos; NPQ, non-photochemical 53 quenching of chlorophyll fluorescence; PSII, photosystem II; RLC, rapid light curve; XC, 54 xanthophyll cycle 
58 Estuarine intertidal flats belong to the most productive ecosystems on Earth (MacIntyre et al., 59 1996; Underwood and Kromkamp, 1999) and they have a central role in structuring the food60 web of coastal areas (Kromkamp and Forster, 2006). A large part of the strong productivity of 61 intertidal flats is due to the microphytobenthos (MPB) (Admiraal, 1984; MacIntyre et al., 62 1996; Underwood and Kromkamp, 1999) which in temperate seas is mainly dominated by 63 benthic diatoms (Méléder et al., 2007; Ribeiro et al., 2013). Benthic and planktonic diatoms 64 are essential primary producers which contribute to about $40 \%$ of the marine primary 65 production; they also play a major role in the silica and nitrogen biogeochemical cycles 66 (Armbrust, 2009). The MPB diatoms constitute the bulk of the diatom diversity (Kooistra et 67 al., 2007). They can be divided in three main growth forms which mainly differ in their life in 68 the sediment (Kooistra et al., 2007; Ribeiro et al., 2013): i) the epipelon comprises motile 69 species free-living in between sediment particles (Herlory et al., 2004), ii) the epipsammon 70 which lives attached to sediment particles, and iii) the tychoplankton which presumably have 71 an amphibious life style (i.e. both sediment and water column) (e.g. Sabbe et al., 2010).

72 Epipelon and epipsammon growth forms show distinct distribution among intertidal habitats 73 characterised by different types of sediment (Sabbe, 1993; Méléder et al., 2007; Ribeiro et al., 74 2013). Epipelon dominates cohesive muddy sediments (> 90\% of MPB; Haubois et al., 2005), 75 while epipsammon dominates less cohesive sandy sediments (> 95\% of MPB; Méléder et al., 76 2007). Because of different habitats, epipelon and epipsammon have evolved different ways of 77 coping with their intertidal environment. Epipelon displays vertical 'migration' following 78 endogenous tidal/dial rhythms and environmental stimuli (Saburova and Polikarpov, 2003; 79 Consalvey et al., 2004; Coelho et al., 2011): typically, during daylight emersion, epipelic 
80 diatoms move to the sediment surface and form a dense biofilm, while before immersion they

81 migrate downward. Epipsammon lives more or less firmly attached (stalked or adnate forms)

82 to individual sand grain including some species able to exert micro-movements within the

83 sphere of grains. Tychoplankton (which is sometimes considered as resuspended epipelon

84 and/or epipsammon during immersion; MacIntyre et al., 1996) can live either as part of MPB

85 or of phytoplankton, depending on the hydrodynamics (Koh et al., 2006); it can contribute to

86 up to one third of phytoplankton (Guarini et al., 2004; Brito et al., 2012).

87 Environmental cues can rapidly vary to an extreme in intertidal flats (Admiraal, 1984; Paterson

88 and Hagerthey, 2001) and impair the photosynthetic productivity of MPB diatoms (i.e.

89 photoinhibition) (Blanchard et al., 2004; Serôdio et al., 2008). In order to prevent such

90 situation, benthic diatoms have evolved diverse responses that can be distinguished in two

91 main types: behaviour and physiology. Only epipelon can escape from a combination of

92 sometimes harsh environmental conditions at the sediment surface by 'migrating' downward to

93 the most optimal conditions (i.e. the so-called 'behavioural photoprotection'; (Admiraal, 1984;

94 Kromkamp et al., 1998; Consalvey et al., 2004; Serôdio et al., 2006), especially as regards to

95 salinity (Sauer et al., 2002). In contrast, all growth forms use physiological processes for the 96 fast regulation of photochemistry (i.e. 'physiological photoprotection'; (Lavaud, 2007; Goss

97 and Jakob, 2010; Depauw et al., 2012; Lepetit et al., 2012). In diatoms, two physiological 98 processes are important in field situation (Brunet and Lavaud, 2010; Lavaud and Goss, 2014):

99 i) the non-photochemical quenching of chlorophyll (Chl) fluorescence (NPQ) (Depauw et al., 100 2012; Lepetit et al., 2012; Lavaud and Goss, 2014), and ii) the partly related light-dependent 101 conversion of diadinoxanthin (DD) to diatoxanthin (DT) by the DD de-epoxidase (i.e. the 102 'xanthophyll cycle', XC) (Brunet and Lavaud, 2010; Goss and Jakob, 2010). In benthic 
103 diatoms, NPQ and XC have been scarcely studied in situ: it varies with the diurnal and tidal 104 cycles, season, latitude (Serôdio et al., 2005; van Leeuwe et al., 2009; Chevalier et al., 2010; 105 Serôdio et al., 2012), and with the position of diatom cells within the sediment and along the 106 intertidal elevation gradient (Jesus et al., 2009; Cartaxana et al., 2011). The respective 107 importance of behavioural and physiological responses in epipelon has received a major 108 interest (Mouget et al., 2008; van Leeuwe et al., 2009; Perkins et al., 2010b; Cartaxana et al., 109 2011; Serôdio et al., 2012). These studies have shown that although motility is essential for an 110 optimal response to the changes in environmental conditions, NPQ and XC remain important 111 features, and even compensate for migration under conditions where motility is limited, to 112 finely tune photosynthetic efficiency. Also, a recent analysis of NPQ and XC abilities among 113 the growth forms of MPB diatoms has revealed a clear relationship between growth form and 114 capacity for physiological photoprotection (Barnett et al., 2014), i.e. while epipsammon shows 115 the highest NPQ and XC capacity, epipelon and tychoplankton shows the lowest ones, 116 reflecting their respective motility and adaptation to a low light (LL) environment (i.e. 117 tychoplankton is either buried in sediment or resuspended in a turbid water column; Roncarati 118 et al., 2008).

119 Changes in light intensity and temperature are often considered as the two major forcings of 120 the photosynthetic productivity of MPB diatoms (Guarini et al., 2006). Surprisingly, changes 121 in salinity have been less studied in benthic diatoms, while in planktonic diatoms it is known to 122 induce modification of community species diversity (Thessen et al., 2005; Dijkman and 123 Kromkamp, 2006; Muylaert et al., 2009; Petrou et al., 2011), and of growth and photosynthesis 124 (Thessen et al., 2005; Dijkman and Kromkamp, 2006; Petrou et al., 2011). Salinity often co125 varies with other environmental gradients like light and temperature in the case of high 
126 salinities (due to pore-water evaporation in the upper-layer of the sediment) and with nutrient 127 concentrations in the case of low salinities (due to the discharge of estuarine rivers) (Admiraal 128 and Peletier, 1980; Underwood and Provot, 2000; Thornton et al., 2002). Although early works 129 stated that MPB diatoms are highly tolerant to a wide range of salinity changes (Williams, 130 1964; Admiraal, 1977; Admiraal and Peletier, 1980), further studies have shown that salinity 131 changes, often combined with high light (HL), impairs the growth from a salinity of 40 and 132 above (Natana Murugaraj and Jeyachandran, 2007; Scholz and Liebezeit, 2012), it reduces the 133 photosynthetic performance (Roncarati et al., 2008; Le Rouzic, 2012) via (photo-)oxidative 134 stress (Rijstenbil, 2003, 2005; Roncarati et al., 2008), and it can modify the motility of epipelic 135 diatoms in the sediment (Sauer et al., 2002) via changes in the excretion of 136 exopolysaccaharides (Apoya-Horton et al., 2006). Furthermore, although the different growth 137 forms of MPB diatoms pertain to habitats in which the salinity can differentially vary due to 138 the degree of cohesion of sediment (Paterson and Hagerthey, 2001), to our knowledge, no 139 study explored if they show different photophysiological response to a combine high salinity140 HL stress and if it correlates to their habitat-associated growth form. The objectives of the 141 present study were therefore to determine i) if a higher salinity can increase the negative effect 142 of HL on the photosynthetic efficiency, ii) if three representatives belonging to each of the 143 growth forms of MPB diatoms react differently to a combined high salinity-HL stress.

\section{2. Materials and methods}

146 2.1. Sediment grain size, pore-water salinity, temperature and MPB biomass of sediment

147 Parameters were measured at different seasons and for two sites of the Atlantic French coast: 148 the bay of Brouage and the bay of Bourgneuf; see Haubois et al. (2005) and Méléder et al. 
149 (2007) for a respective characterization of the two sampling sites (see Table 1 and Figure 1 for 150 all details). Sediment grain size was determined with a laser granulometer (Mastersizer 2000, 151 Malvern Instruments, UK) as previously described (Méléder et al., 2007). The mud fraction 152 (grain size $<63 \mu \mathrm{m}$ ) of each sample was determined using the software Gradistat (Blott and 153 Pye, 2001). Sediment samples were centrifuged for $10 \mathrm{~min}$ at $3500 \mathrm{~g}$ and salinity was 154 measured on the supernatant with a sensor TetraCon325 (WTW, Weilhem, Germany). The 155 temperature at the sediment surface was measured every $30 \mathrm{~s}$ with a universal data logger 156 (ULM-500, Walz Effeltrich Germany) equipped with a plane temperature sensor (accessory of 157 the ULM-500). The sediment content of chlorophyll $a$ ( $\mu \mathrm{g} \mathrm{Chl} a . \mathrm{g}^{\mathrm{dry}}$ sediment ${ }^{-1}$ ) was used as 158 a proxy for MPB biomass. Chl $a$ was extracted and measured as previously described (Herlory 159 et al., 2004): spectrofluorimetric measurement (Turner TD-700 fluorometer) was performed on 160 supernatant of sediment samples after lyophilisation, extraction $\left(90 \%\right.$ acetone, $12 \mathrm{~h}, 4^{\circ} \mathrm{C}$, in the 161 dark, continuous shaking) and centrifugation $10 \mathrm{~min}$ at $4000 \mathrm{~g}$.

\subsection{Diatom culture conditions}

164 Three species belonging to the three main growth forms of MPB diatoms were used: 1) 165 Epipelon, Navicula phyllepta (Culture Collection Yerseke-The Netherlands CCY9804, 166 isolated in the Westerschelde estuary, North sea, The Netherlands); 2) Epipsammon, Biremis 167 lucens (Nantes Culture Collection-France NCC360, isolated in the bay of Bourgneuf, 168 Atlantic,France; 3) Tychoplankton, Plagiogrammopsis vanheurckii (NCC186-2, isolated in the 169 bay of Bourgneuf). Cultures were grown in batch sterile artificial seawater F/2 medium 170 completed with Tropic Marin artificial sea salt (Dr. Biener GmbH, Germany) at a salinity of

17133 , and enriched with $\mathrm{NaHCO}_{3}\left(80 \mathrm{mg} \mathrm{L}^{-1}\right.$ final concentration). Temperature was $20^{\circ} \mathrm{C}$ and 
172 light was $60 \mu \mathrm{mol}$ photons $\mathrm{m}^{-2} \mathrm{~s}^{-1}$ (white fluorescent tubes L58W/840, OSRAM, Germany)

173 with a $16 \mathrm{~h}: 8 \mathrm{~h}$ light:dark photoperiod. When cultures reached exponential phase, cells were

174 harvested by gentle centrifugation ( $5 \mathrm{~min}, 4000 \mathrm{~g}$ ), resuspended to a concentration of $6 \pm 1 \mathrm{mg}$

$175 \mathrm{Chl} a \mathrm{~mL}^{-1}$. For this purpose, Chl $a$ concentration was determined according to the Jeffrey and

176 Humphrey (1975) spectrophotometric method. Diatom suspensions were continuously stirred

177 under the growth conditions for at least $1 \mathrm{~h}$ before the high light (HL) and salinity treatments.

178

179 2.3. High light (HL) and salinity treatments

180 Diatom cells were exposed for $1 \mathrm{~h}$ to a range of increasing salinities $(33,37,41$ and 45$)$ under 181 the growth light intensity and under HL intensity (10x the growth light intensity, $600 \mu \mathrm{mol}$ 182 photons $\mathrm{m}^{-2} \mathrm{~s}^{-1}$ ) at $20^{\circ} \mathrm{C}$. During each treatment, cells were stirred to prevent settling. Each 183 condition was measured in triplicate. The temperature, light and salinity values/ranges were 184 chosen according to the in situ measurements (see Table 1 and Figure 1) in order to reproduce 185 the environment experienced by MPB diatoms in Spring (see the Results section, paragraph 186 3.1). Increased salinity was obtained by implementing the sterile artificial seawater F/2 187 medium with increasing amounts of Tropic Marin artificial sea salt (Dr. Biener GmbH, 188 Germany). HL was provided by white fluorescent tubes (FQ 54W/865 LO, OSRAM, 189 Germany).

\subsection{Pigment analyses}

192 At the end of each salinity and light treatments, $1 \mathrm{~mL}$ of diatom suspension was filtered on a 193 membrane filter (Membrane Isopore Polycarbonate 1.2- $\mu \mathrm{m}$ RTTP filter, $25 \mathrm{~mm}$ diameter, 194 Merck Millipore, Ireland), quickly frozen in liquid nitrogen and stored at $-80^{\circ} \mathrm{c}$ until further 
195 analysis. Pigment extraction and determination of pigment content were performed as

196 previously described (Barnett et al., 2014). Chl a.cell ${ }^{-1}$ was calculated by counting the number 197 of cells microscopically with a Malassez's counting chamber. The de-epoxidation state (DES 198 in \%) was calculated as DES = [(DT / DD + DT $) \times 100]$, where DD is the diadinoxanthin, the 199 epoxidized form, and DT is the diatoxanthin, the de-epoxidized form.

2.5. Chl fluorescence yield and rapid light curves (RLCs)

202 For a complete overview of the definition, measurement and calculation of the fluorescence 203 levels and of the photophysiological parameters, see Table 2. Chl fluorescence yield was 204 monitored with a Diving-PAM fluorometer (Walz, Germany) on a $2.5 \mathrm{~mL}$ stirred and $20^{\circ} \mathrm{C}$ 205 controlled diatom suspension (see Lavaud et al., 2004). Before measurement, the cells were 206 dark-adapted for $15 \mathrm{~min}$, and a saturating pulse $\left(3600 \mu \mathrm{mol}\right.$ photons $\mathrm{m}^{-2} \mathrm{~s}^{-1}$, duration $\left.0.4 \mathrm{~ms}\right)$ 207 was fired to measure $F_{0}, F_{m}$ and $F_{v} / F_{m}$. For RLCs (Perkins et al., 2010a), the diatom 208 suspension was exposed to 8 successive increasing intensities $\left(29-1038 \mu\right.$ mol photons.m $\left.{ }^{-2} . \mathrm{s}^{-1}\right)$ 209 of $60 \mathrm{~s}$ each. At the end of each RLC-light step exposure, $\mathrm{F}_{\mathrm{m}}$ ' was measured. RLCs allow 210 constructing rETR vs. E curves; from the fitted rETR-E curves (Eilers and Peeters, 1988), $211 \mathrm{rETR}_{\mathrm{m}}, \alpha, \mathrm{E}_{\mathrm{k}}$ can be extracted.

212

213 3. Results

214 3.1. Pore-water salinity and MPB biomass in different sediments of the French Atlantic coast

215 The changes in pore-water salinity in the upper layer (first $1 \mathrm{~cm}$ ) was measured over different 216 seasons at two sites of the French Atlantic coast characterised by two sediment types: 1) a site 217 with $95 \%$ of cohesive muddy sediment which is known to be dominated by a community of 
218 epipelic diatoms, and especially Navicula phyllepta, throughout the year (Haubois et al., 219 2005); 2) a site with a mix of muddy and sandy (thus less cohesive) sediment which is known 220 to be dominated by a community of epipsammic diatoms where Biremis lucens and 221 Plagiogrammopsis vanheurckii are typical (Méléder et al., 2007). Overall, pore-water salinity 222 varied between 29 and 48 during the $3 \mathrm{~h}$ emersion period (Table 2). As expected, variations 223 over an emersion were higher in summer than in winter, and over seasons in cohesive than in 224 less cohesive sediment with an overall minimum and maximum variation during an emersion 225 of 2.3 and 8.3 , respectively.

226 The changes in pore-water salinity were further deciphered at the two sites during the course of 227 an emersion in Spring at two depths in the upper layer of sediments (Fig. 1). Large changes in 228 pore-water salinity occurred within only $1.5 \mathrm{~h}$ : mean $\Delta 5.1$ and $\Delta 3.5$ for the muddy and the 229 muddy-sandy sediment, respectively. Nevertheless, these changes were mainly (muddy 230 sediment, Fig. 1A) and even exclusively (muddy-sandy sediment, Fig. 1B) observed in the first $2310.5 \mathrm{~cm}$ where most of the MPB biomass was present (Fig. 1C). In the deeper sediment layer ($232 \quad 0.5-1 \mathrm{~cm})$, a high equivalent MPB biomass (40.5 \pm 3.5 and $48.5 \pm 5.3 \mu \mathrm{g} \mathrm{Chl} a \mathrm{~g} \mathrm{sediment}^{-1}$ in 233 muddy and muddy-sandy sediment, respectively) was observed and the pore-water salinity was 234 close to 33: $34.0 \pm 0.7$ in mud and $33.0 \pm 1.3$ in muddy sand.

236 3.2. Photophysiological response of Navicula phyllepta (epipelon), Biremis lucens 237 (epipsammon) and Plagiogrammopsis vanheurckii (tychoplankton) to a combined high 238 salinity-HL stress

239 The PSII activity of the three species was assessed by measuring $F_{v} / F_{m}$ and ФPSII, as well as 240 the RLCs photophysiological parameters $\left(\alpha, \operatorname{rETR}_{\mathrm{m}}\right.$ and $\left.\mathrm{E}_{\mathrm{k}}\right)$ (see Table 2 ). While in LL- 
241 acclimated cells $\mathrm{F}_{\mathrm{v}} / \mathrm{F}_{\mathrm{m}}$ and ФPSII did not change significantly with salinity (Tables 3 and 5),

242 HL treatment induced a significant mean decrease in $\mathrm{F}_{\mathrm{v}} / \mathrm{F}_{\mathrm{m}}(N$. phyllepta, $-8.3 \pm 1.0 \%<B$.

243 lucens, $-11.3 \pm 1.7 \%<P$. vanheurckii, $-37.3 \pm 1.7 \%)$ and in ФPSII (N. phyllepta, $-6.3 \pm 1.5 \%$

$244<$ B. lucens, $-10.0 \pm 3.3 \%$ ) independent of salinity (Tables 3 and 5). Only in P. vanheurckii

245 ФPSII changes were salinity-dependent, i.e. $-11.5 \pm 3.5 \%$ from 33-37 and $-28.5 \pm 1.5 \%$ for

246 41-45 (Table 3). The RLCs photophysiological parameters ( $\alpha, \mathrm{rETR}_{\mathrm{m}}$ and $\mathrm{E}_{\mathrm{k}}$, see Table 2 )

247 changed differently depending on the species and salinity/light treatments. $N$. phyllepta cells

248 were not significantly affected either by changes in salinity nor by the HL treatment (Fig. 2

249 and Table 5). In B. lucens $\mathrm{LL}$ acclimated cells, $\mathrm{E}_{\mathrm{k}}$ and $\mathrm{rETR}_{\mathrm{m}}$ were significantly affected by

250 salinity (Fig. 2 and Table 5) and, as expected, $\alpha$ and $E_{k}$ were significantly lower and higher,

251 respectively, after HL treatment (Table 5) although only for a limited range of salinities: up to

25241 for $\alpha$ and up to 37 for $\mathrm{E}_{\mathrm{k}}$. In $\mathrm{HL}$ cells, further salinity raising induced an increase in $\alpha$

$253(+25.5 \pm 3.5 \%)$ and a subsequent decrease in $\mathrm{E}_{\mathrm{k}}(-39 \pm 3 \%)$ (Fig. 2). It was in P. vanheurckii

$254 \alpha, \mathrm{rETR}_{\mathrm{m}}$ and $\mathrm{E}_{\mathrm{k}}$ showed the most pronounced changes with salinity and HL treatment (Fig. 2

255 and Table 5). $\alpha$ decreased in both LL acclimated cells (-23 $\pm 14 \%)$ and after HL treatment (-39

$256 \pm 5 \%$, especially from a salinity of 33 to 37$) \cdot \mathrm{rETR}_{\mathrm{m}}$ followed an opposite trend, and

257 significantly increased with salinity by a mean factor of up to $1.60 \pm 0.13$, and independent of

258 the light treatment (Table 5). As a consequence, $\mathrm{E}_{\mathrm{k}}$ significantly increased together with

259 salinity for both light treatments $(\mathrm{x} 1.96 \pm 0.3$ and $\mathrm{x} 1.53 \pm 0.3$ for HL and LL cells, 260 respectively).

261 The photoprotective response of the species was assessed by measuring NPQ and the XC 262 components and operation (Tables 3 and 4). NPQm of LL acclimated cells (Table 3) was on 
263 average $0.224 \pm 0.135$ ( N. phyllepta), $0.332 \pm 0.018$ (B. lucens) and $0.645 \pm 0.105(P$. 264 vanheurckii) and, as expected, it significantly increased during the HL treatment (Tables 3 and 265 5) as follows: P. vanheurckii (x $1.6 \pm 0.3$ for all salinities) $<N$. phyllepta (x $1.8 \pm 0.3$ for all 266 salinities except 45, x 2.5) < B. lucens (x $2.2 \pm 0.4$ for all salinities). Only in P. vanheurckii LL 267 acclimated cells, $\mathrm{NPQ}_{\mathrm{m}}$ significantly decreased by $-30 \%$ from a salinity of 33 to 45 (Tables 3 268 and 5). DES was much higher in LL acclimated cells of $P$. vanheurckii $(40 \pm 4 \%)$ than in $N$. 269 phyllepta $(12 \pm 3 \%)$ and B. lucens $(7 \pm 1 \%)$ (Fig. 3). During the HL treatment, and 270 independent of salinity, DES significantly increased to a different extent (P. vanheurckii, $58 \pm$ $2712 \%>$ B. lucens, $39 \pm 3 \%>N$. phyllepta, $31 \pm 2 \%$ ) (Fig. 3 and Table 5). Interestingly, in $N$. 272 phyllepta, while diatoxanthin (DT) significantly increased during HL (i.e. due to 273 diadinoxanthin, DD, de-epoxidation), DD did not similarly decreased (Tables 4 and 5), as it 274 would have been expected, arguing for a de novo synthesis of DD during HL. Out from DD 275 and DT, there was no additional significant pigment changes in the three species whatever the 276 treatment except a significant HL-salinity independent decrease in Chl a.cell $^{-1}(-20.3 \pm 4.5 \%)$ 277 in N. phyllepta.

278 The higher sensitivity of $P$. vanheurckii to salinity alone was further illustrated by the fact that 279 the combination with the HL treatment did not significantly change some of the 280 photophysiological parameters $\left(\alpha, \mathrm{rETR}_{\mathrm{m}}, \mathrm{E}_{\mathrm{k}}, \mathrm{NPQ}_{\mathrm{m}}\right)$ in contrast to N. phyllepta and B. lucens 281 (Table 5). 
4.1. Pore-water salinity changes in Atlantic French coast intertidal flats and their potential effects on intertidal MPB diatoms

286 In the field, the upper layer sediment pore-water salinity can highly $(\Delta 5)$ and rapidly (within $2871.5 \mathrm{~h}$ ) increase, and reach values as high as 48 in Summer (values up to 55-60 were even 288 reported elsewhere, Roncarati et al., 2008; Serôdio et al., 2008). Nevertheless, high salinity 289 events are not restricted to hot sunny days and also occur at moderate temperature $\left(16-20^{\circ} \mathrm{C}\right)$, 290 as shown here in Spring, due to wind-driven desiccation (Williams, 1964; Sauer et al., 2002) in 291 the first $0.5 \mathrm{~cm}$ of the sediment (where the bulk of the MPB biomass inhabits). Changes in the 292 sediment pore-water salinity depend on the sediment cohesion with higher values and 293 amplitude in cohesive sediment probably due to the trapping (and subsequent higher 294 evaporation) of pore-water at the surface (Paterson and Hagerthey, 2001; Sauer et al., 2002). 295 Therefore, although temperature may be optimal (20-25 ${ }^{\circ} \mathrm{C}$, Blanchard et al., 1997; Scholz and 296 Liebezeit, 2012), HL and high salinity conditions may occur in the sediment upper layer 297 during Spring-early Summer emersion by the Atlantic French coast. These conditions may 298 differentially impair the photosynthetic efficiency of the main growth forms of MPB as regards 299 to the sediment cohesion of their respective habitat or their amphibious life. The HL-high 300 salinity combination has been rarely studied before (Rijstenbil, 2003, 2005; Roncarati et al., 301 2008). Most previous works focused on low salinity stress combined to nutrient gradient due to 302 estuarine rivers discharge (Admiraal and Peletier, 1980; Underwood and Provot, 2000; 303 Thornton et al., 2002) and on the long-term effect of salinity changes (most often measured by 304 specific growth, Williams, 1964; Jackson et al., 1992; Underwood and Provot, 2000; Natana 305 Murugaraj and Jeyachandran, 2007; Scholz and Liebezeit, 2012), instead of effects (including 
306 short-term exposure) on the photosynthetic efficiency (Admiraal, 1977; Admiraal and Peletier, 307 1980; Roncarati et al., 2008).

311 The photosynthesis of the three examined species responded differently to the combination of 312 HL and salinity stress. In our conditions, N. phyllepta, the photosynthetic efficiency was not 313 largely impaired neither by high salinity nor HL alone or both in combination (i.e. changes in 314 PSII and RLCs photophysiological parameters were not $>10 \%$ on average). Noticeably, HL 315 induced a decrease in Chl $a$. cell ${ }^{-1}$ that was not observed in the two other species. It shows the 316 ability to lower the overexcitation of the whole photosynthetic machinery under HL stress 317 (Brunet et al., 2011). In contrast, in B. lucens, the photosynthetic electron transport rate $318\left(\mathrm{rETR}_{\mathrm{m}}\right)$ was slightly but significantly affected by high salinity alone. Additionally, the 319 photoacclimatory-coupled decrease in $\alpha$ and increase in $E_{k}$, that illustrates the decrease of the 320 excitation pressure on PSII (Perkins et al., 2006; Cruz and Serôdio, 2008; Lefebvre et al., 321 2011), were abolished by higher salinities (from 37 on). Nevertheless, in our moderately 322 stressful conditions, it did not largely impaired PSII activity (decrease in $\mathrm{F}_{\mathrm{v}} / \mathrm{F}_{\mathrm{m}}$ and $\Phi$ PSII at 323 maximum $\sim 11 \%$ ). The high salinity-dependent inhibition of photoacclimation was not 324 observed in $P$. vanheurckii for which the decrease of the excitation pressure on PSII was 325 obviously a key response in all conditions. While under HL alone, $\alpha$ and $\mathrm{E}_{\mathrm{k}}$ modulation was 326 enough, under high salinity alone and combined with $\mathrm{HL}$, the additional increase in $\mathrm{rETR}_{\mathrm{m}}$, 327 possibly through a stronger activation of the Calvin cycle enzymes (Nymark et al., 2009), was 328 necessary to cope with the stress. These changes in the photosynthetic efficiency were 
329 sufficient for $P$. vanheurckii to cope with salinity stress alone but not when it was it was 330 combined with HL (strong ФPSII decrease for salinities > 41 on), supporting its HL sensitivity 331 (strong $F_{v} / F_{m}$ decrease) due to its adaptation to a $L L$ environment (low $\alpha$ and $E_{k}$; see also 332 Barnett et al., 2014).

333 In parallel to modification in PSII-related photophysiological parameters, all species exerted a 334 photoprotective response but to a different extent. In contrast to prolonged high salinity 335 exposure (Rijstenbil, 2005), HL DES increase was independent of salinity in all species. 336 Hence, the de-epoxidase enzyme, responsible for the light-dependent conversion of DD to DT, 337 does not seem to be influenced by a short (1 h) salinity stress. DT is well-known to i) scavenge 338 reactive oxygen species (ROS) and to help preventing the peroxidation of lipids of the 339 thylakoid membrane (Lepetit et al., 2010), ii) participate to NPQ (Goss and Jakob, 2010; 340 Lavaud et al., 2012; Lavaud and Lepetit, 2013). In contrast to the two other species, in $N$. 341 phyllepta DD de-epoxidation was accompanied by DD de novo synthesis, a way to enhance the 342 capacity to further synthesize DT in case of prolonged stress (Lepetit et al., 2013). Probably 343 due to the shortness of high salinity exposure, there was no significant increase in fucoxanthin 344 and $\beta$-carotene, a well-known pigment response to oxidative stress additional to the $\mathrm{XC}$ 345 (Dambeck and Sandmann, 2014; Tefler, 2014). As expected, $\mathrm{NPQ}_{\mathrm{m}}$ was higher in B lucens 346 than in N. phyllepta, while it was higher than previously observed in $P$. vanheurckii probably 347 due to i) different growth light conditions which generated a higher DES, and ii) the different 348 way of measuring NPQ (RLCs vs. Non-Sequential Light Curves-NSLCs) (Barnett et al., 2014). 349 HL NPQ increased was impacted by salinity depending on the species: while NPQ increase 350 was similar (about 1.6x) for all salinities in $P$. vanheurckii, it was higher (about $2.2 \mathrm{x}$ ) in $B$ 351 lucens, and it reached an even higher level (2.5x) for a salinity of 45 in $N$. phyllepta. These 
352 observations clearly illustrate how i) NPQ helped to dissipate the excess of light excitation 353 energy in PSII when the photosynthetic machinery was slowed-down by salinity, ii) $N$. 354 phyllepta appeared to be insensitive to all high salinities lower than 45. Strikingly, in $P$. 355 vanheurckii, NPQ decreased linearly $\left(-0.018 \pm 0.001\right.$ NPQ unit. salinity unit $\left.{ }^{-1}\right)$ illustrating the 356 high salinity-dependent NPQ inhibition disregard of the high amount of DT synthesised in this 357 species. Most probably here, NPQ decrease and discrepancy between DES and NPQ might be 358 due to a stronger involvement of DT in the prevention of lipid peroxidation by ROS (Lepetit et 359 al., 2010; Lepetit and Lavaud, 2013).

4.3 Relationship between the response of intertidal MPB diatoms to a combined high salinity-

HL stress and their habitat-related growth form

363 The photophysiological response of N. phyllepta, B. lucens and P. vanheurckii to the combined 364 high salinity-HL conditions fitted well with their respective growth form and original habitat. 365 The relationship between photophysiology and the different growth forms of MPB diatoms to 366 light alone was already documented before (Barnett et al., 2014).

369 N. phyllepta photochemistry was not affected neither by the high salinity stress alone, nor by 370 the combination of HL and high salinity, illustrating an adaptation to potentially extreme 371 conditions of light and salinity at the surface of cohesive (muddy) sediment. This is in 372 agreement with previous reports on the high tolerance to salinity changes of Navicula sp. 373 representatives (Underwood and Provot, 2000; Scholz and Liebezeit, 2012), and to a larger 374 extent of epipelon representatives (Williams, 1964; Admiraal, 1977; Admiraal and Peletier, 
375 1980; Clavero et al., 2000). In response to light stress, epipelic diatoms use both vertical 376 motility in the sediment and physiology (Mouget et al., 2008; van Leeuwe et al., 2009; Perkins 377 et al., 2010b; Cartaxana et al., 2011; Serôdio et al., 2012; Barnett et al., 2014). Although in our 378 experiments motility was abolished, the photophysiological response of $N$. phyllepta confirms 379 the likeliness of an equivalent balance between motility and physiology to respond to salinity 380 stress. Surprisingly, N. phyllepta did not deploy a strong photophysiological response pointing 381 out to other intra-cellular means that explain its relative insensitivity to high salinity (at least 382 up to 45). For instance, they use proline to adjust their osmotic balance (Natana Murugaraj and 383 Jeyachandran, 2007). Most importantly, cells surround themselves with exopolysaccharides 384 (EPS) to minimize the negative impact of desiccation and high salinity (Sauer et al., 2002) on 385 motility: i) it was shown on a natural assemblage that a shift in salinity from 35 to 45 386 generated a -30\% migration of the cells at the surface of sediment (Sauer et al., 2002); ii) in 387 controlled laboratory conditions, motility can be even abolished at a salinity of 50 (Apoya388 Horton et al., 2006). This phenomenon is based on the decrease of the gliding speed of the 389 cells (Apoya-Horton et al., 2006) and its rapidity (5 s; Apoya-Horton et al., 2006) might be 390 related to intracellular calcium responses (Falciatore et al., 2000; Apoya-Horton et al., 2006). 391 Excretion of EPS during high salinity events allows cell attachment, a prerequisite for cell 392 gliding (Apoya-Horton et al., 2006) that, in field conditions, indeed supports the vertical cell 393 migration to apparently escape extreme salinities. Therefore, the motility response of epipelic 394 diatoms was speculated to be part of an adaptive strategy to respond the sometimes highly 395 changing environment, including light and salinity, at the surface of cohesive sediment, 396 (Admiraal, 1984). 


\subsubsection{Tychoplankton}

Similar to epipelon, tychoplankton movement modalities, when it is buried in sediment at low tide (Roncarati et al., 2008), are strongly influenced by salinity changes (Apoya-Horton et al., 2006). Additionally, high salinity drives the detachment of cells from their substratum, which could be a strategy to avoid longer exposure for this amphibious group (Apoya-Horton et al., 2006). Nevertheless, as reported before (Roncarati et al., 2008) and here, the physiological response to salinity (combined or not with HL) of tychoplankton seems to be more complex than the one of epipelon. They appear highly sensitive to salinities > 35 (Underwood and Provot, 2000) including drastic growth limitation at salinities > 40 (Rijstenbil, 2003; Scholz and Liebezeit, 2012). In our conditions, salinities from 35 on generated a strong photophysiological response in $P$. vanheurckii: its photochemical machinery acclimated just like high salinities would render it more light sensitive (see paragraph 4.2.). This general response was likely related to the linear lowering of NPQ with high salinities together with the anti-oxidative stress response (i.e. strong DT synthesis). It supports the obvious salinity (and light) sensitivity of $P$. vanheurckii. This is confirmed by previous studies on another tychoplankton representative (Cylindrotheca closterium) (Rijstenbil, 2003, 2005; Roncarati et al., 2008). In response to the high salinity- and/or HL-dependent ROS generation, the intracellular pools and activity of important players of the oxidative stress response (i.e. the reduced glutathione-GSH, the superoxide dismutase-SOD enzyme) increased. Albeit such protective response, cells could not avoid significant lipid peroxidation (Roncarati et al., 2008). Peroxidation of lipids of the thylakoid membrane disturbs osmoregulation (Rijstenbil, 2003, 2005) which might explain the synthesis of intracellular osmoregulators like free sugars (mannose, Paul, 1979), amino acids (taurine, Jackson et al., 1992; and proline, Natana 
421 Murugaraj and Jeyachandran, 2007). Moreover, leakage of the thylakoid membrane can impair

422 the build-up of the transthylakoid $\Delta \mathrm{pH}$ (i.e. loss of membrane potential, Rijstenbil, 2005),

423 which would well explain the NPQ decrease with increasing salinities (Lavaud and Lepetit, 424 2013; Lavaud and Goss, 2014). All together, these observations fit well with an adaptation of 425 tychoplankton to salinities $\sim 33$ as it is mostly the case in the water column (when cells are 426 resuspended at high tide) or buried in sediment (when cells settle down at low tide) as 427 observed here from $-0.5 \mathrm{~cm}$ down (see paragraph 4.1.).

\section{4.3.3. Epipsammon}

430 The response of epipsammon to salinity changes is much less documented. To our knowledge, 431 only Scholz and Liebezeit (2012) investigated the negative impact of salinity on the growth of 432 episammic species like Achnantes spp. and Amphora spp.. Because it lives attached to 433 sediment particles and the light penetration is deeper in (less cohesive) sandy sediment, the 434 epipsammon photophysiological response to HL is efficient (Barnett et al., 2014). Here, under 435 LL, B. lucens was relatively insensitive to high salinity. Nevertheless, and although DES and 436 NPQ were high, the ability to decrease the excitation pressure on PSII during HL exposure was 437 partially abolished by salinities $>37-41$. As a consequence, $\mathrm{rETR}_{\mathrm{m}}$ decreased, thus potentially 438 impairing the photosynthetic productivity. While B. lucens is well adapted to cope with HL 439 and with high salinity, it appears less well adapted to the combination of the two. This fits well 440 with the fact that in its natural habitat, even if the light climate can be extreme, changes in 441 salinity remain moderate i) even in the first $0.5 \mathrm{~cm}$ of sediment, and ii) especially deeper 442 where a significant part of the epipsammon biomass inhabits, as shown here (see paragraph 443 4.1.). 


\section{4.4. Conclusions}

446 The photophysiology of representatives of the three main groups of intertidal MPB diatoms 447 (i.e. epipelon, epipsammon and tychoplankton) differentially responded to a high salinity stress 448 alone or combined with moderate HL exposure. While the representative of epipelon was 449 relatively insensitive to these conditions, the tychoplankton representative was highly sensitive 450 to both, and the epipsammon representative was sensitive mainly to the stress combination. 451 These specific responses fitted well with i) their natural habitat (i.e. more or less cohesive 452 sediment) for which light climate and changes in salinity differ, ii) their growth form (i.e. 453 motile, immotile or amphibious) which determines their probability to be confronted to a 454 combined high salinity-HL stress, and their capacity to eventually escape from it (i.e. 455 epipelon). Although light and temperature are regarded as major drivers of the photosynthetic 456 productivity of MPB in Western Europe intertidal mudflats (Kromkamp et al., 2006), salinity 457 increase during emersion obviously can non-negligibly modulate the MPB photosynthesis 458 when it is combined with HL (and temperature) according to the weather conditions and 459 sediment type. It nevertheless appears mostly restricted to epipsammon and tychoplankton, and 460 in field conditions, although likely stronger than in the present study, its effect probably 461 remains negligible compared to HL stress. 


\section{Acknowledgements}

464 The authors acknowledge the Centre National de la Recherche Scientifique-CNRS (program 465 'chercheurs invités' 2011), the University of La Rochelle-ULR (ACI 'chercheurs invités' 466 2011), the Region Poitou-Charentes (program 'chercheurs invités' 2013), the Contrat Plant 467 Etat Région-CPER Littoral (2007-13), and the Natural Science and Engineering Research 468 Council of Canada-NSERC (grant \#262210-2011) for their financial support. 


\section{References}

471 Admiraal, W., 1977. Salinity tolerance of benthic estuarine diatoms as tested with a rapid 472 polarographic measurement of photosynthesis. Mar Biol 39, 11-18.

473 Admiraal, W., 1984. The ecology of estuarine sediment inhabiting diatoms. Prog Phycol Res

$474 \quad 3,269-314$.

475 Admiraal, W., Peletier, H., 1980. Distribution of diatom species on an estuarine mud flat and 476 experimental analysis of the selective effect of stress. J Exp Mar Bio Ecol 46, 157-175.

477 Apoya-Horton, M.D., Yin, L., Underwood, G.J.C., Gretz, M.R., 2006. Movement modalities 478 and responses to environmental changes of the mudflat diatom Cylindrotheca closterium 479 (Bacillariophyceae). J Phycol 42, 379-390.

480 Armbrust, E.V., 2009. The life of diatoms in the world's oceans. Nature 459, 185-192.

481 Barnett, A., Méléder, V., Blommaert, L., Lepetit, B., Gaudin, P., Vyverman, W., Sabbe, K., 482 Dupuy, C., Lavaud, J., In revision. Growth form defines photoprotective capacity in intertidal 483 benthic diatoms. ISME J., in press, doi:10.1038/ismej.2014.105.

484 Blanchard, G., Guarini, J.-M., Dang, C., Richard, P., 2004. Characterizing and quantifying 485 photoinhibition in intertidal microphytobenthos. J. Phycol. 40, 692-696.

486 Blanchard, G., Guarini, J.-M., Gros, P., Richard, P., 1997. Seasonal effect on the 487 photosynthesic capacity of intertidal microphytobenthos and temperature. J. Phycol. 33, 723488728.

489 Blott, S.J., Pye, K., 2001. GRADISTAT: a grain size distribution and statistics package for the 490 analysis of unconsolidated sediments. Earth Surf Proc Land 26, 1237-1248. 
491 Brito, A.C., Fernandes, T.F., Newton, A., Facca, C., Tett, P., 2012. Does microphytobenthos 492 resuspension influence phytoplankton in shallow systems ? A comparison through a Fourier 493 series analysis. Est Coast Shelf Sci 110, 77-84.

494 Brunet, C., Lavaud, J., 2010. Can the xanthophyll cycle help extract the essence of the 495 microalgal functional response to a variable light environment ? J Plankton Res 32, 1609$496 \quad 1617$.

497 Brunet, C., Johnsen, G., Lavaud, J., Roy, S., 2011. Pigments and photoacclimation processes. 498 In Roy S, Johnsen G, Llewellyn C, Skarstad E (eds) Phytoplankton Pigments in 499 Oceanography: Guidelines to Modern Methods, Series: Oceanographic Methodologies Vol. 2500 Chapter 11, SCOR-UNESCO Publishing, Cambridge University Press, pp 445-471.

501 Cartaxana, P., Ruivo, M., Hubas, C., Davidson, I., Serôdio, J., Jesus, B., 2011. Physiological 502 versus behavioral photoprotection in intertidal epipelic and epipsammic benthic diatom 503 communities. J Exp Mar Biol Ecol 405, 120-127.

504 Chevalier, E.M., Gévaert, F., Créach, A., 2010. In situ photosynthetic activity and 505 xanthophylls cycle development of undisturbed microphytobenthos in an intertidal mudflat. J 506 Exp Mar Biol Ecol 385, 44-49.

507 Clavero, E., Hernandez-Mariné, M., Grimalt, J.O., Garcia-Pichet, F., 2000. Salinity tolerance 508 of diatoms ftom Thalassic hypersaline environments. J Phycol 36, 1021-1034.

509 Coelho, H., Vieira, S., Serôdio, J., 2011. Endogenous versus environmental control of vertical 510 migration by intertidal benthic microalgae. Eur J Phycol 46, 271-281.

511 Consalvey, M., Paterson, D.M., Underwood, G.J.C., 2004. The ups and downs of life in a 512 benthic biofilm: migration of benthic diatoms. Diatom Res 19, 181-202. 
513 Cruz, S., Serôdio, J., 2008. Relationship of rapid light curves of variable fluorescence to 514 photoacclimation and non-photochemical quenching in a benthic diatom. Aquat Bot 88, 256515264.

516 Dambeck, M., Sandmann, G., 2014. Antioxidative activities of algal keto carotenoids acting as 517 antioxidative protectants in the chloroplast. Photochem. Photobiol. 90, 814-819.

518 Depauw, F.A., Rogato, A., d'Alcala, M.R., Falciatore, A., 2012. Exploring the molecular basis 519 of responses to light in marine diatoms. J Exp Bot 63, 1575-1591.

520 Dijkman, N.A., Kromkamp, J.C., 2006. Photosynthetic characteristics of the phytoplankton in 521 the Scheldt estuary: community and single-cell fluorescence measurements. Eur J Phycol 41, $522 \quad 425-434$.

523 Eilers, P.H.C., Peeters, J.C.H., 1988. A model for the relationship between light intensity and 524 the rate of photosynthesis in phytoplankton. Ecol Model 42, 199-215.

525 Falciatore, A., d'Alcala, M.R., Croot, P., Bowler, C., 2000. Perception of environmental 526 signals by a marine diatom. Science 288, 2363-2366.

527 Goss, R., Jakob, T., 2010. Regulation and function of xanthophyll cycle-dependent 528 photoprotection in algae. Photosynth Res 106, 103-122.

529 Guarini, J.-M., Blanchard, G., Richard, P., 2006, Modelling the dynamics of the 530 microphytobenthic biomass and primary production in European intertidal mudflats. In: 531 Kromkamp, J., de Brouwer, J.F.C., Blanchard, G., Forster, R.M., Créach, V. (Eds.), 532 Functioning of microphytobenthos in estuaries. Royal Netherlands Academy of Arts and 533 Sciences, Amsterdam, pp. 187-226. 
534 Guarini, J.-M., Gros, P., Blanchard, G., Richard, P., Fillon, A., 2004. Benthic contribution to 535 pelagic microalgal communities in two semi-enclosed, European-type littoral ecosystems 536 (Marennes-Oléron Bay and Aiguillon Bay, France). J Sea Res 52, 241-258.

537 Haubois, A.-G., Sylvestre, F., Guarini, J.-M., Richard, P., Blanchard, G.F., 2005. Spatio538 temporal structure of the epipelic diatom assemblage from an intertidal mudflat in Marennes539 Oleron Bay, France. Est Coast Shelf Sci 64, 385-394.

540 Herlory, O., Guarini, J.-M., Richard, P., Blanchard, G.F., 2004. Microstructure of 541 microphytobenthic biofilm and its spatio-temporal dynamics in an intertidal mudflat 542 (Aiguillon Bay, France). Mar Ecol Prog Ser 282, 33-44.

543 Jackson, A.E., Ayer, S.W., Laycock, M.V., 1992. The effect of salinity on growth and amino 544 acid composition in the marine diatiom Nitzschia pungens. Can J Bot 70, 2198-2201.

545 Jeffrey, S.W., Humphrey, G.R., 1975. New spectrophotometric equations for determining 546 chlorophylls a, b, c1 and c2 in higher plants, algae and natural phytoplankton. Biochem 547 Physiol Pflanzen Bd 167, 191-194.

548 Jesus, B.M., Brotas, V., Ribeiro, L., Mendes, C.R., Cartaxana, P., Paterson, D.M., 2009. 549 Adaptations of microphytobenthos assemblages to sediment type and tidal position. Cont $550 \quad$ Shelf Res 29, 1624-1634.

551 Koh, C.-H., Khim, J.S., Araki, H., Yamanishi, H., Mogi, H., Koga, K., 2006. Tidal 552 resuspension of microphytobenthic chlorophyll $a$ in a Nanaura mudflat, Saga, Arieke Sea, 553 Japan: flood-ebb and spring-neap variations. Mar. Ecol. Prog. Ser. 312, 85-100.

554 Kooistra, W.H.C.F., Gersonde, R., Medlin, L.K., Mann, D.G., 2007, The origin and the 555 evolution of the diatoms: Their adaptation to a planktonic existence. In: Falkowski, P.G., 
556 Knoll, A.H. (Eds.), Evolution of Primary Producers in the Sea. Elsevier Academic Press, 557 Burlington, pp. 207-249.

558 Kromkamp, J., Barranguet, C., Peene, J., 1998. Determination of microphytobenthos PSII 559 quantum efficiency and photosynthetic activity by means of variable chlorophyll fluorescence.

560 Mar Ecol Prog Ser 162, 45-55.

561 Kromkamp, J., Forster, R.M., 2006, Developments in microphytobenthos primary productivity 562 studies. In: Kromkamp, J., de Brouwer, J.F.C., Blanchard, G., Forster, R.M., Créach, V. 563 (Eds.), Functioning of microphytobenthos in estuaries. Royal Netherlands Academy of Arts 564 and Sciences, Amsterdam, pp. 9-30.

565 Lavaud, J., 2007. Fast regulation of photosynthesis in diatoms: Mechanisms, evolution and 566 ecophysiology. Funct Plant Sci Biotech 267, 267-287.

567 Lavaud, J., Goss, R., 2014, The peculiar features of non-photochemical fluorescence 568 quenching in diatoms and brown algae. In: Demmig-Adams, B., Adams, W.W.I., Garab, G., 569 Govindjee (Eds.), Non-Photochemical Fluorescence Quenching and Energy Dissipation in 570 Plants, Algae, and Cyanobacteria. Springer, Dordrecht, p. In press.

571 Lavaud, J., Lepetit, B., 2013. An explanation for the inter-species variability of the 572 photoprotective non-photochemical chlorophyll fluorescence quenching in diatoms. Biochim 573 Biophys Acta 1827, 294-302.

574 Lavaud, J., Materna, A.C., Sturm, S., Vugrinec, S., Kroth, P.G., 2012. Silencing of the 575 violaxanthin de-epoxidase gene in the diatom Phaeodactylum tricornutum reduces 576 diatoxanthin synthesis and non-photochemical quenching. PLoS ONE 7, e36806.

577 Lavaud, J., Rousseau, B., Etienne, A.-L., 2004. General features of photoprotection by energy 578 dissipation in planktonic diatoms (Bacillariophyceae). J Phycol 40, 130-137. 
579 Le Rouzic, B., 2012. Changes in photosynthetic yield (Fv/Fm) responses of salt-marsh 580 microalgal communities along an osmotic gradient (Mont-Saint-Michel Bay, France). Est 581 Coast Shelf Sci 115, 326-333.

582 Lefebvre, S., Mouget, J.L., Lavaud, J., 2011. Duration of rapid light curves for determining in 583 situ the photosynthetis of microphytobenthos biofilms. Aquat. Bot. 95, 1-8.

584 Lepetit, B., Goss, R., Jakob, T., Wilhelm, C., 2012. Molecular dynamics of the diatom 585 thylakoid membrane under different light conditions. Photosynth Res 111, 245-257.

586 Lepetit, B., Sturm, S., Rogato, A., Gruber, A., Sachse, M., Falciatore, A., Kroth, P.G., Lavaud, 587 J., 2013. High light acclimation in the secondary plastids containing diatom Phaeodactylum 588 tricornutum is triggered by the redox state of the plastoquinone pool. Plant Physiol 161, 853589865.

590 Lepetit, B., Volke, D., Gilbert, M., Wilhelm, C., Goss, R., 2010. Evidence for the existence of 591 one antenna-associated, lipid-dissolved and two protein-bound pools of diadinoxanthin cycle 592 pigments in diatoms. Plant Physiol 154, 1905-1920.

593 MacIntyre, H.L., Geider, J.R., Miller, D.C., 1996. Microphytobenthos: The ecological role of 594 the 'secret garden' of unvegetated, shallow-water marine habitats. I. Distribution, abundance 595 and primary production. Estuaries 19, 186-201.

596 Méléder, V., Rincé, Y., Barillé, L., Gaudin, P., Rosa, P., 2007. Spatiotemporal changes in 597 microphytobenthos assemblages in a macrotidal flat (Bourgneuf Bay, France). J Phycol 43, 598 1177-1190.

599 Mouget, J.L., Perkins, R., Consalvey, M., Lefebvre, S., 2008. Migration or photoacclimation 600 to prevent high irradiance and UV-B damage in marine microphytobenthic communities. 601 Aquatic Microbial Ecology 52, 223-232. 
602 Muylaert, K., Sabbe, K., Vyverman, W., 2009. Changes in phytoplankton diversity and 603 community composition along the salinity gradient of the Schelde estuary (Belgium/The 604 Netherlands). Est Coast Shelf Sci 82, 335-340.

605 Natana Murugaraj, G., Jeyachandran, S., 2007. Effect of salinity stress on the marine diatom 606 Amphora coffeaeformis (Ag.) Kuetz. (Bacillariophyceae) in relation to proline accumulation. 607 Seaweed Res Utiln 29, 227-231.

608 Nymark, M., Valle, K.C., Brembu, T., Hancke, K., Winge, P., Andresen, K., Johnsen, G., 609 Bones, A.M., 2009. An integrated analysis of molecular acclimation to high light in the marine 610 diatom Phaeodactylum tricornutum. Plos One 4, e7743.

611 Paterson, D.M., Hagerthey, S.E., 2001, Microphytobenthos in contrasting coastal ecosystems: 612 Biology and dynamics. In: Reise, K. (Ed.), Ecological Comparisons of Sedimentary Shores. 613 Springer-Verlag, Berlin Heidelberg, pp. 106-125.

614 Paul, J.S., 1979. Osmoregulation in the marine diatom Cylindrotheca fusiformis. J Phycol 15, $615 \quad 280-284$.

616 Perkins, R.G., Kromkamp, J.C., Serôdio, J., Lavaud, J., Jesus, B.M., Mouget, J.-L., Lefebvre, 617 S., Forster, R.M., 2010a, The Application of variable chlorophyll fluorescence to 618 microphytobenthic biofilms. In: Suggett, D.J., Prášil, O., Borowitzka, M.A. (Eds.), 619 Chlorophyll a Fluorescence in Aquatic Sciences: Methods and Applications. Springer 620 Netherlands, pp. 237-275.

621 Perkins, R.G., Lavaud, J., Serôdio, J., Mouget, J.-L., Cartaxana, P., Rosa, P., Barille, L., 622 Brotas, V., Jesus, B.M., 2010b. Vertical cell movement is a primary response of intertidal 623 benthic biofilms to increasing light dose. Mar Ecol Prog Ser 416, 93-103. 
624 Perkins, R.G., Mouget, J.-L., Lefebvre, S., Lavaud, J., 2006. Light response curve 625 methodology and possible implications in the application of chlorophyll fluorescence to 626 benthic diatoms. Mar Biol 149, 703-712.

627 Petrou, K., Doblin, M.A., Ralph, P.J., 2011. Heterogeneity in the photoprotective capacity of 628 three Antarctic diatoms during short-term changes in salinity and temperature. Mar Biol 158, 629 1029-1041.

630 Ribeiro, L., Brotas, V., Rincé, Y., Jesus, B.M., 2013. Structure and diversity of intertidal 631 benthic diatom assemblages in contrasting shores: A case study from the Tagus estuary. J 632 Phycol.

633 Rijstenbil, J.W., 2003. Effects of UVB radiation and salt stress on growth, pigments and 634 antioxidative defence of the marine diatom Cylindrotheca closterium. Mar. Ecol. Prog. Ser. $635254,37-47$.

636 Rijstenbil, J.W., 2005. UV- and salinity-induced oxidative effects in the marine diatom 637 Cylindrotheca closterium during simulated emersion. Mar. Biol. 147, 1063-1073.

638 Roncarati, F., Rijstenbil, J.W., Pistocchi, R., 2008. Photosynthetic performance, oxidative 639 damage and antioxidants in Cylindrotheca closterium in response to high irradiance, UVB 640 irradiance and salinity. Mar. Biol. 153, 965-973.

641 Sabbe, K., 1993. Short-term fluctuations in benthic diatom numbers on an intertidal sandflat in 642 the Westerschelde estuary (Zeeland, The Netherlands). Hydrobiologia 269-270, 275-284.

643 Sabbe, K., Vanelslander, B., Ribeiro, L., Witkowski, A., Muylaert, K., Vyverman, W., 2010. 644 A new genus, Pierrecomperia gen. nov., a new species and two new combinations in the 645 marine diatom family Cymatosiraceae. Vie et Milieu 60, 243-256. 
646 Saburova, M.A., Polikarpov, I.G., 2003. Diatom activity within soft sediments: behavioural 647 and physiological processes. Mar Ecol Prog Ser 251, 115-126.

648 Sauer, J., Wenderoth, K., Maier, U.G., Rhiel, E., 2002. Effect of salinity, light and time on the 649 vertical migration of diatom assemblages. Diatom Res 17, 189-203.

650 Scholz, B., Liebezeit, G., 2012. Growth responses of 25 benthic marine Wadden Sea diatoms 651 isolated from the Solthörn tidal flat (southern North Sea) in relation to varying culture 652 conditions. Diatom Res 27, 65-73.

653 Serôdio, J., Coelho, H., Vieira, S., Cruz, S., 2006. Microphytobenthos vertical migratory 654 photoresponse as characterised by light-response curves of surface biomass. Est Coast Shelf 655 Sci 68, 547-556.

656 Serôdio, J., Cruz, S., Vieira, S., Brotas, V., 2005. Non-photochemical quenching of 657 chlorophyll fluorescence and operation of the xanthophyll cycle in estuarine 658 microphytobenthos. J Exp Mar Biol Ecol 326, 157-169.

659 Serôdio, J., Ezequiel, J., Barnett, A., Mouget, J.-L., Méléder, V., Laviale, M., Lavaud, J., 660 2012. Efficiency of photoprotection in microphytobenthos: Role of vertical migration and the 661 xanthophyll cycle against photoinhibition. Aquatic Microbial Ecology 67, 161-175.

662 Serôdio, J., Vieira, S., Cruz, S., 2008. Photosynthetic activity, photoprotection and 663 photoinhibition in intertidal microphytobenthos as studied in situ using variable chlorophyll 664 fluorescence. Cont Shelf Res 28, 1363-1375.

665 Telfer, A., 2014. Singlet oxygen production by PSII under light stress: Mechanism, detection 666 and the photoprotective role of $\beta$-carotene. Plant Cell Physiol. 55, 1216-1223.

667 Thessen, A.E., Dortch, Q., Parsons, M.L., Morrison, W., 2005. Effect of salinity on Pseudo668 Nitzschia species (Bacillariophyceae) growth and distribution. J Phycol 41, 21-29. 
669 Thornton, D.C.O., Dong, L.F., Underwood, G.J.C., Nedwell, D.B., 2002. Factors affecting 670 microphytobenthic biomass, species composition and production in the Colne Estuary (UK). 671 Aquatic Microbial Ecology 27, 285-300.

672 Underwood, G.J.C., Kromkamp, J., 1999, Primary production by phytoplankton and 673 microphytobenthos in estuaries. In: Nedwell, D.B., Raffaelli, D.G. (Eds.), Adv Ecol Res. 674 Academic Press, pp. 93-153.

675 Underwood, G.J.C., Provot, L., 2000. Determining the environmental preferences of four 676 estuarine epipelic diatom taxa: growth across a range of salinity, nitrate and ammonium 677 conditions. Eur J Phycol 35, 173-182.

678 van Leeuwe, M.A., Brotas, V., Consalvey, M., Forster, R.M., Gillespie, D., Jesus, B., 679 Roggeveld, J., Gieskes, W.W.C., 2009. Photacclimation in microphytobenthos and the role of 680 the xanthophylls pigments. Eur J Phycol 43, 123-132.

681 Williams, R.B., 1964. Division rates of salt marsh diatoms in relation to salinity and cell size. 682 Ecology 45, 877-880. 


\section{Figure legends}

686

687 Figure 1

688 Evolution of the pore-water sediment salinity (A, B) and chlorophyll $a(\mathrm{Chl} a)$ biomass

689 (C) during emersion in the upper sediment layer $(0-0.5 \mathrm{~cm}$, black columns / 0.5-1 cm, 690 white columns for A- and B-; Mud, black columns / Muddy sand, white columns for C-) 691 in two sites of the French Atlantic coast with two different sediment types (A- Mud; B692 Muddy sand) in Spring. The representative day was 2012/04/20 for the muddy site and 693 2012/05/06 for the muddy sandy site. They showed the following features: emersion maximum 694 at $11: 25 \mathrm{AM} \pm 5 \mathrm{~min}$, no rain, sediment surface temperature $=16.6 \pm 1.8{ }^{\circ} \mathrm{C}$ and $20.6 \pm 4.3{ }^{\circ} \mathrm{C}$ 695 for the muddy and the muddy sandy sites, respectively; based on these temperatures, a $20^{\circ} \mathrm{C}$ 696 experimental temperature was further used. Values are averages \pm standard deviation $(n=3)$.

$698 \quad$ Figure 2

699 Photophysiological parameters in Navicula phyllepta, Biremis lucens and $700 \quad$ Plagiogrammopsis vanheurckii exposed to different salinities (33 to 45). Abbreviations: LL, 701 growth low light $\left(60 \mu \mathrm{mol} \mathrm{m} \mathrm{s}^{-2}\right.$ photons $)$; HL, after $1 \mathrm{~h}$ high light $\left(600 \mu \mathrm{mol} \mathrm{m} \mathrm{s}^{-2}\right.$ photons $)$ 702 treatment; $\alpha$-Alpha, maximum light efficiency use; rETR $_{\mathrm{m}}$, maximum relative electron 703 transport rate; $\mathrm{E}_{\mathrm{k}}$, light saturation coefficient. Values are averages \pm standard deviation $(\mathrm{n}=3)$. 704

705 Figure 3

706 Rate of de-epoxidation (DES) of diadinoxanthin (DD) to diatoxanthin (DT) in Navicula 707 phyllepta, Biremis lucens and Plagiogrammopsis vanheurckii exposed to different salinities 
708 (33 to 45). Abbreviations: DES $=[(\mathrm{DD}+\mathrm{DT}) / \mathrm{DT} \times 100] ; \mathrm{LL}$, growth low light $\left(60 \mu \mathrm{mol} \mathrm{m}{ }^{-2}\right.$

$709 \mathrm{~s}^{-1}$ photons), white columns; HL, after 1h high light $\left(600 \mu \mathrm{mol} \mathrm{m} \mathrm{m}^{-2} \mathrm{~s}^{-1}\right.$ photons $)$ treatment,

710 black columns. Values are averages \pm standard deviation $(n=3)$.

711 
712 Table 1_Juneau et al.

713 Pore-water salinity measured during emersion in the upper sediment layer (first $1 \mathrm{~cm}$ ) in 714 two sites of the French Atlantic coast with two different sediment types and at different 715 seasons. Values are averages \pm standard deviation $(n=9$ to 12$)$.

\begin{tabular}{|c|c|c|c|c|c|}
\hline Sediment type & $\begin{array}{l}\text { Season } \\
\text { period }\end{array}$ & Min & Max & $\begin{array}{l}\text { Emersion } \Delta \\
\max \end{array}$ & $\begin{array}{l}\text { Emersion } \Delta \\
\text { mean }\end{array}$ \\
\hline $\begin{array}{l}\text { Mud } \\
(95.1 \pm 0.1 \% \mathrm{mud} /\end{array}$ & $\begin{array}{l}\text { Winter } \\
02 / 19-02 / 24\end{array}$ & $29.0 \pm 1.2$ & $34.1 \pm 1.1$ & 2.3 & $1.3 \pm 0.6$ \\
\hline \multirow[t]{2}{*}{$4.9 \pm 0.1 \%$ sand $)$} & $\begin{array}{l}\text { Spring } \\
04 / 19-04 / 22\end{array}$ & $32.5 \pm 1.1$ & $38.8 \pm 1.1$ & 5.1 & $4.4 \pm 1.0$ \\
\hline & $\begin{array}{l}\text { Summer } \\
07 / 13-07 / 26\end{array}$ & $35.8 \pm 0.2$ & $48.2 \pm 0.7$ & 8.3 & $4.6 \pm 2.7$ \\
\hline $\begin{array}{l}\text { Muddy sand } \\
(57.9 \pm 7.9 \% \text { sand } /\end{array}$ & $\begin{array}{l}\text { Spring } \\
04 / 05-07 / 05\end{array}$ & $30.8 \pm 1.0$ & $35.4 \pm 2.8$ & 3.2 & $1.9 \pm 1.2$ \\
\hline $42.1 \pm 7.9 \% \mathrm{mud})$ & $\begin{array}{l}\text { Fall } \\
\text { 09/30-10/02 }\end{array}$ & $32.8 \pm 0.4$ & $37.3 \pm 2.7$ & 3.8 & $3.7 \pm 0.2$ \\
\hline
\end{tabular}


Table 2_Juneau et al.

Photophysiological parameters used in this study, their meaning and how they were measured. Abbreviations: Chl, chlorophyll; DD, diadinoxanthin; DT, diatoxanthin; E, light intensity; PSII, photosystem II; RLCs, Rapid Light Curves. See the Materials and Methods section for further details.

\begin{tabular}{|c|c|c|c|c|}
\hline Parameter & Unit & Definition & Photophysiological meaning & Measurement conditions \\
\hline $\mathrm{F}_{0}$ & No units & $\begin{array}{l}\text { Minimum PSII Chl } \\
\text { fluorescence yield }\end{array}$ & $\begin{array}{l}\text { Used to calculate } \mathrm{F}_{\mathrm{v}} / \mathrm{F}_{\mathrm{m}} \\
\text { (see below) }\end{array}$ & $\begin{array}{l}\text { Measured with RLCs after } 15 \\
\text { min of dark acclimation }\end{array}$ \\
\hline $\mathrm{F}_{\mathrm{m}}$ & No units & $\begin{array}{l}\text { Maximum PSII Chl } \\
\text { fluorescence yield }\end{array}$ & $\begin{array}{l}\text { Used to calculate } \mathrm{F}_{\mathrm{v}} / \mathrm{F}_{\mathrm{m}} \text { and NPQ } \\
\text { (see below) }\end{array}$ & $\begin{array}{l}\text { Measured with RLCs during a } \\
\text { saturating pulse after } 15 \text { min of } \\
\text { dark acclimation }\end{array}$ \\
\hline $\mathrm{F}_{\mathrm{v}} / \mathrm{F}_{\mathrm{m}}$ & No units & $\begin{array}{l}\text { Maximum PSII } \\
\text { quantum yield; } \\
\mathrm{F}_{\mathrm{v}} / \mathrm{F}_{\mathrm{m}}=\left(\mathrm{F}_{\mathrm{m}}-\mathrm{F}_{0}\right) / \mathrm{F}_{\mathrm{m}}\end{array}$ & $\begin{array}{l}\text { Maximum potential quantum } \\
\text { efficiency of PSII photochemistry }\end{array}$ & $\begin{array}{l}\text { See the above measurement } \\
\text { conditions for } \mathrm{F}_{0} \text { and } \mathrm{F}_{\mathrm{m}}\end{array}$ \\
\hline
\end{tabular}




\begin{tabular}{|c|c|c|c|c|}
\hline $\mathrm{F}_{\mathrm{m}}$ & No units & $\mathrm{F}_{\mathrm{m}}$ for illuminated cells & Used to measure NPQ and rETR & $\begin{array}{l}\text { Measured with RLCs during a } \\
\text { saturating pulse after } 60 \mathrm{~s} \text { of } \\
\text { illumination at specific } \mathrm{E}\end{array}$ \\
\hline$\overline{\text { ФPSII }}$ & No units & $\begin{array}{l}\text { Operational } \\
\text { quantum yield; } \\
\text { ФPSII = }\left(\mathrm{F}_{\mathrm{m}},-\mathrm{F}\right) / \mathrm{F}_{\mathrm{m}}\end{array}$ & $\begin{array}{l}\text { Maximum effective quantum } \\
\text { efficiency of PSII photochemistry }\end{array}$ & $\begin{array}{l}\text { See the above measurement } \\
\text { conditions for } \mathrm{F}_{0} \text { and } \mathrm{F}_{\mathrm{m}} ; \mathrm{F} \text { is the } \\
\text { steady-state of } \mathrm{Chl} \text { fluorescence } \\
\text { measured after } 60 \mathrm{~s} \text { illumination } \\
\text { at specific } \mathrm{E}\end{array}$ \\
\hline NPQ & No units & $\begin{array}{l}\text { Non-photochemical } \\
\text { quenching of Chl } \\
\text { fluorescence; } \\
\mathrm{NPQ}=\mathrm{F}_{\mathrm{m}} / \mathrm{F}_{\mathrm{m}}{ }^{\prime}-1\end{array}$ & $\begin{array}{l}\text { Estimates the photoprotective } \\
\text { dissipation of excess energy }\end{array}$ & Measured with RLCs \\
\hline rETR & $\mu \mathrm{mol}$ electrons $\mathrm{m}^{-2} \mathrm{~s}^{-1}$ & $\begin{array}{l}\text { Relative electron } \\
\text { transport rate of PSII; }\end{array}$ & $\begin{array}{l}\text { Effective quantum yield of } \\
\text { photochemistry } v s . \mathrm{E}\end{array}$ & Measured with RLCs \\
\hline
\end{tabular}




\begin{tabular}{|c|c|c|c|c|}
\hline & & rETR = ФPSII x E & & \\
\hline$\alpha$ & $\begin{array}{l}\mu \mathrm{mol} \text { electrons } \mathrm{m}^{-2} \mathrm{~s}^{-1} \\
/ \mu \mathrm{mol} \text { photons. } \mathrm{m}^{-2} \cdot \mathrm{s}^{-} \\
1\end{array}$ & $\begin{array}{l}\text { rETR-E curve initial } \\
\text { slope }\end{array}$ & Maximum light efficiency use & $\begin{array}{l}\text { Derived from fitted rETR-E } \\
\text { curves (Eilers and Peeters, 1988) }\end{array}$ \\
\hline $\mathrm{rETR}_{\mathrm{m}}$ & $\mu \mathrm{mol}$ electrons $\mathrm{m}^{-2} \mathrm{~s}^{-1}$ & $\begin{array}{l}\text { rETR-E curve } \\
\text { asymptote }\end{array}$ & $\begin{array}{l}\text { Maximum relative photosynthetic } \\
\text { electron transport rate }\end{array}$ & $\begin{array}{l}\text { Derived from fitted rETR-E } \\
\text { curves (Eilers and Peeters, 1988) }\end{array}$ \\
\hline$\overline{E_{k}}$ & $\mu \mathrm{mol}$ photons. $\mathrm{m}^{-2} \cdot \mathrm{s}^{-1}$ & $\mathrm{E}_{\mathrm{k}}=\mathrm{rETR}_{\mathrm{m}} / \alpha$ & Light saturation coefficient & $\begin{array}{l}\text { Derived from fitted rETR-E } \\
\text { curves (Eilers and Peeters, 1988) }\end{array}$ \\
\hline $\mathrm{NPQ}_{\mathrm{m}}$ & No units & Maximum NPQ & $\begin{array}{l}\text { Maximum ability for dissipation } \\
\text { of excess energy }\end{array}$ & $\begin{array}{l}\text { Measured at maximum E of } \\
\text { RLCs }\end{array}$ \\
\hline DES & $\%$ & $\mathrm{DES}=[\mathrm{DT} /(\mathrm{DD}+\mathrm{DT})$ & De-epoxidation state of DD to DT & Measured during growth at LL \\
\hline
\end{tabular}




\begin{tabular}{|l|l|l|l|l|}
\hline & x 100] & & and after 1 h HL treatment \\
\hline
\end{tabular}




\section{Table 3_Juneau et al.}

Photochemical potential and non-photochemical fluorescence quenching in Navicula phyllepta (N.p.), Biremis lucens (B.I.) and Plagiogrammopsis vanheurckii (P.v.) exposed to different salinities. Abbreviations: LL, growth low light $\left(60 \mu \mathrm{mol} \mathrm{m} \mathrm{m}^{-2} \mathrm{~s}^{-1}\right.$ photons $)$; HL, high light $\left(600 \mu \mathrm{mol} \mathrm{m} \mathrm{m}^{-2} \mathrm{~s}^{-1}\right.$ photons). Definitions and conditions of measurement of $\mathrm{F}_{\mathrm{v}} / \mathrm{F}_{\mathrm{m}}, \Phi P S I I$ and $\mathrm{NPQ}_{\mathrm{m}}$ are listed in Table 2. Values are averages \pm standard deviation $(\mathrm{n}=3)$.

\begin{tabular}{|c|c|c|c|c|c|c|c|}
\hline & & \multicolumn{3}{|l|}{$\mathrm{LL}$} & \multicolumn{3}{|l|}{$\mathrm{HL}$} \\
\hline Species & Salinity & $\mathrm{F}_{\mathrm{v}} / \mathrm{F}_{\mathrm{m}}$ & ФPSII & $\mathrm{NPQ}_{\mathrm{m}}$ & $\overline{F_{v}} / F_{m}$ & ФPSII & $\mathrm{NPQ}_{\mathrm{m}}$ \\
\hline \multirow[t]{4}{*}{ N.p. } & 33 & $\begin{array}{l}0.724 \\
\pm 0.011\end{array}$ & $\begin{array}{l}0.599 \\
\pm 0.030\end{array}$ & $\begin{array}{l}0.306 \\
\pm 0.060\end{array}$ & $\begin{array}{l}0.667 \\
\pm 0.028\end{array}$ & $\begin{array}{l}0.551 \\
\pm 0.031\end{array}$ & $\begin{array}{l}0.547 \\
\pm 0.053\end{array}$ \\
\hline & 37 & $\begin{array}{l}0.727 \\
\pm 0.019\end{array}$ & $\begin{array}{l}0.597 \\
\pm 0.031\end{array}$ & $\begin{array}{l}0.315 \\
\pm 0.044\end{array}$ & $\begin{array}{l}0.659 \\
\pm 0.007\end{array}$ & $\begin{array}{l}0.568 \\
\pm 0.041\end{array}$ & $\begin{array}{l}0.485 \\
\pm 0.070\end{array}$ \\
\hline & 41 & $\begin{array}{l}0.730 \\
\pm 0.010\end{array}$ & $\begin{array}{l}0.600 \\
\pm 0.068\end{array}$ & $\begin{array}{l}0.250 \\
\pm 0.022\end{array}$ & $\begin{array}{l}0.662 \\
\pm 0.006\end{array}$ & $\begin{array}{l}0.559 \\
\pm 0.038\end{array}$ & $\begin{array}{l}0.542 \\
\pm 0.017\end{array}$ \\
\hline & 45 & $\begin{array}{l}0.724 \\
\pm 0.015\end{array}$ & $\begin{array}{l}0.600 \\
\pm 0.051\end{array}$ & $\begin{array}{l}0.259 \\
\pm 0.038\end{array}$ & $\begin{array}{l}0.674 \\
\pm 0.009\end{array}$ & $\begin{array}{l}0.571 \\
\pm 0.019\end{array}$ & $\begin{array}{l}0.653 \\
\pm 0.016\end{array}$ \\
\hline \multirow[t]{3}{*}{ B.1. } & 33 & $\begin{array}{l}0.694 \\
\pm 0.010\end{array}$ & $\begin{array}{l}0.563 \\
\pm 0.009\end{array}$ & $\begin{array}{l}0.323 \\
\pm 0.097\end{array}$ & $\begin{array}{l}0.629 \\
\pm 0.009\end{array}$ & $\begin{array}{l}0.504 \\
\pm 0.003\end{array}$ & $\begin{array}{l}0.588 \\
\pm 0.142\end{array}$ \\
\hline & 37 & $\begin{array}{l}0.694 \\
\pm 0.012\end{array}$ & $\begin{array}{l}0.554 \\
\pm 0.016\end{array}$ & $\begin{array}{l}0.315 \\
\pm 0.071\end{array}$ & $\begin{array}{l}0.602 \\
\pm 0.010\end{array}$ & $\begin{array}{l}0.498 \pm \\
0.040\end{array}$ & $\begin{array}{l}0.864 \\
\pm 0.186\end{array}$ \\
\hline & 41 & 0.689 & 0.569 & 0.332 & 0.607 & 0.496 & 0.736 \\
\hline
\end{tabular}




\begin{tabular}{|l|l|l|l|l|l|l|l|}
\hline & & \pm 0.020 & \pm 0.008 & \pm 0.024 & \pm 0.041 & \pm 0.039 & \pm 0.332 \\
\cline { 2 - 8 } & 45 & 0.703 & 0.560 & 0.357 & 0.627 & 0.530 & 0.782 \\
& & \pm 0.010 & \pm 0.019 & \pm 0.103 & \pm 0.019 & \pm 0.038 & \pm 0.271 \\
\hline P.v. & 33 & 0.588 & 0.312 & 0.791 & 0.370 & 0.265 & 1.003 \\
& & \pm 0.034 & \pm 0.024 & \pm 0.141 & \pm 0.032 & \pm 0.031 & \pm 0.048 \\
\cline { 2 - 8 } & & 0.539 & 0.292 & 0.622 & 0.352 & 0.270 & 1.178 \\
\cline { 2 - 8 } & 41 & 0.555 & 0.291 & 0.625 & 0.336 & 0.213 & 0.908 \\
& \pm 0.009 & \pm 0.095 & \pm 0.129 & \pm 0.028 & \pm 0.021 & \pm 0.103 \\
\cline { 2 - 8 } & 45 & 0.577 & 0.316 & 0.542 & 0.359 & 0.221 & 0.870 \\
& \pm 0.055 & \pm 0.041 & \pm 0.019 & \pm 0.018 & \pm 0.066 & \pm 0.143 \\
\hline
\end{tabular}




\section{Table 4_Juneau et al.}

Pigments in Navicula phyllepta (N.p.), Biremis lucens (B.l.) and Plagiogrammopsis vanheurckii (P.v.) exposed to different salinities. Abbreviations: LL, growth low light $\left(60 \mu \mathrm{mol} \mathrm{m} \mathrm{m}^{-2} \mathrm{~s}^{-1}\right.$ photons $)$; HL, high light $\left(600 \mu \mathrm{mol} \mathrm{m}^{-2} \mathrm{~s}^{-1}\right.$ photons $)$. Chl $a$, chlorophyll $a$; Chl $c$, chlorophyll $c$; Fx, fucoxanthin; DD, diadinoxanthin; DT, diatoxanthin; $\beta$-car, $\beta$-carotene. Chl $a$ is in pg. cell ${ }^{-1}$; other pigments are in mol. $100 \mathrm{~mol} \mathrm{Chl} a^{-1}$. Values are averages \pm standard deviation $(\mathrm{n}=3)$.

\begin{tabular}{|c|c|c|c|c|c|c|c|c|c|c|c|c|c|}
\hline \multirow[b]{2}{*}{ Species } & \multirow[b]{2}{*}{ Salinity } & \multicolumn{6}{|l|}{$\mathrm{LL}$} & \multicolumn{6}{|l|}{$\mathrm{HL}$} \\
\hline & & Chl $a$ & Chl $c$ & $\mathrm{Fx}$ & 及-car & $\mathrm{DD}$ & DT & Chl $a$ & Chl $c$ & Fx & B-car & DD & DT \\
\hline \multirow[t]{4}{*}{ N.p. } & 33 & $\begin{array}{l}0.830 \\
\pm 0.020\end{array}$ & $\begin{array}{l}33.2 \\
\pm 0.9\end{array}$ & $\begin{array}{l}151.0 \\
\pm 0.9\end{array}$ & $\begin{array}{l}8.6 \\
\pm 8.3\end{array}$ & $\begin{array}{l}33.7 \\
\pm 2.3\end{array}$ & $\begin{array}{l}3.5 \\
\pm 0.2\end{array}$ & $\begin{array}{l}0.716 \\
\pm 0.019\end{array}$ & $\begin{array}{l}37.1 \\
\pm 3.1\end{array}$ & $\begin{array}{r}134.2 \\
\pm 3.5\end{array}$ & $\begin{array}{r}13.0 \\
\pm 5.2\end{array}$ & $\begin{array}{l}30.8 \\
\pm 1.0\end{array}$ & $\begin{array}{l}9.1 \\
\pm 1.9\end{array}$ \\
\hline & 37 & $\begin{array}{l}0.821 \\
\pm 0.065\end{array}$ & $\begin{array}{l}42.2 \\
\pm 8.9\end{array}$ & $\begin{array}{l}157.0 \\
\pm 11.4\end{array}$ & $\begin{array}{l}8.3 \\
\pm 8.5\end{array}$ & $\begin{array}{l}34.1 \\
\pm 1.1\end{array}$ & $\begin{array}{l}3.1 \\
\pm 0.1\end{array}$ & $\begin{array}{l}0.621 \\
\pm 0.043\end{array}$ & $\begin{array}{l}35.9 \\
\pm 2.8\end{array}$ & $\begin{array}{l}131.8 \\
\pm 1.7\end{array}$ & $\begin{array}{r}13.9 \\
\pm 3.7\end{array}$ & $\begin{array}{l}29.1 \\
\pm 2.9\end{array}$ & $\begin{array}{l}9.9 \\
\pm 1.8\end{array}$ \\
\hline & 41 & $\begin{array}{l}0.812 \\
\pm 0.016\end{array}$ & $\begin{array}{l}42.7 \\
\pm 0.8\end{array}$ & $\begin{array}{l}152.1 \\
\pm 5.8\end{array}$ & $\begin{array}{l}14.0 \\
\pm 6.4\end{array}$ & $\begin{array}{r}33.8 \\
\pm 5.6\end{array}$ & $\begin{array}{l}3.0 \\
\pm 0.4\end{array}$ & $\begin{array}{l}0.652 \\
\pm 0.053\end{array}$ & $\begin{array}{l}34.8 \\
\pm 2.4\end{array}$ & $\begin{array}{r}127.8 \\
\pm 1.7\end{array}$ & $\begin{array}{r}12.2 \\
\pm 6.7\end{array}$ & $\begin{array}{l}29.6 \\
\pm 1.6\end{array}$ & $\begin{array}{l}9.4 \\
\pm 2.6\end{array}$ \\
\hline & 45 & $\begin{array}{l}0.793 \\
\pm 0.040\end{array}$ & $\begin{array}{l}40.9 \\
\pm 1.9\end{array}$ & $\begin{array}{l}150.1 \\
\pm 6.1\end{array}$ & $\begin{array}{l}14.1 \\
\pm 5.8\end{array}$ & $\begin{array}{l}33.2 \\
\pm 5.0\end{array}$ & $\begin{array}{l}3.0 \\
\pm 0.2\end{array}$ & $\begin{array}{l}0.607 \\
\pm 0.048\end{array}$ & $\begin{array}{l}33.2 \\
\pm 0.6\end{array}$ & $\begin{array}{l}127.5 \\
\pm 1.4\end{array}$ & $\begin{array}{l}11.3 \\
\pm 5.3\end{array}$ & $\begin{array}{l}28.8 \\
\pm 0.2\end{array}$ & $\begin{array}{l}11.8 \\
\pm 2.6\end{array}$ \\
\hline
\end{tabular}




\begin{tabular}{|c|c|c|c|c|c|c|c|c|c|c|c|c|c|}
\hline \multirow[t]{4}{*}{ B.1. } & 33 & $\begin{array}{l}1.830 \\
\pm 0.280\end{array}$ & $\begin{array}{l}27.1 \\
\pm 2.7\end{array}$ & $\begin{array}{l}76.8 \\
\pm 4.5\end{array}$ & $\begin{array}{l}7.1 \\
\pm 6.2\end{array}$ & $\begin{array}{l}19.5 \\
\pm 0.2\end{array}$ & $\begin{array}{l}1.7 \\
\pm 0.8\end{array}$ & $\begin{array}{l}1.642 \\
\pm 0.201\end{array}$ & $\begin{array}{r}25.7 \\
\pm 1.2\end{array}$ & $\begin{array}{r}72.5 \\
\pm 4.4\end{array}$ & $\begin{array}{l}2.2 \\
\pm 1.9\end{array}$ & $\begin{array}{l}14.5 \\
\pm 2.1\end{array}$ & $\begin{array}{l}8.6 \\
\pm 0.2\end{array}$ \\
\hline & 37 & $\begin{array}{l}1.661 \\
\pm 0.105\end{array}$ & $\begin{array}{r}24.3 \\
\pm 3.2\end{array}$ & $\begin{array}{l}70.0 \\
\pm 6.6\end{array}$ & $\begin{array}{l}2.8 \\
\pm 1.4\end{array}$ & $\begin{array}{l}17.7 \\
\pm 0.9\end{array}$ & $\begin{array}{l}1.2 \\
\pm 1.0\end{array}$ & $\begin{array}{l}1.626 \\
\pm 0.186\end{array}$ & $\begin{array}{r}24.4 \\
\pm 2.9\end{array}$ & $\begin{array}{r}69.2 \\
\pm 8.9\end{array}$ & $\begin{array}{l}3.5 \\
\pm 0.5\end{array}$ & $\begin{array}{r}13.8 \\
\pm 2.1\end{array}$ & $\begin{array}{l}9.7 \\
\pm 0.8\end{array}$ \\
\hline & 41 & $\begin{array}{l}1.883 \\
\pm 0.210\end{array}$ & $\begin{array}{l}29.0 \\
\pm 4.6\end{array}$ & $\begin{array}{l}87.3 \\
\pm 7.3\end{array}$ & $\begin{array}{l}3.6 \\
\pm 0.5\end{array}$ & $\begin{array}{l}23.4 \\
\pm 0.8\end{array}$ & $\begin{array}{l}1.1 \\
\pm 0.9\end{array}$ & $\begin{array}{l}1.554 \\
\pm 0.088\end{array}$ & $\begin{array}{r}22.8 \\
\pm 0.9\end{array}$ & $\begin{array}{r}63.9 \\
\pm 3.5\end{array}$ & $\begin{array}{l}3.5 \\
\pm 0.1\end{array}$ & $\begin{array}{r}12.8 \\
\pm 2.2\end{array}$ & $\begin{array}{l}8.9 \\
\pm 1.1\end{array}$ \\
\hline & 45 & $\begin{array}{l}1.749 \\
\pm 0.220\end{array}$ & $\begin{array}{r}26.6 \\
\pm 2.8\end{array}$ & $\begin{array}{l}76.7 \\
\pm 7.9\end{array}$ & $\begin{array}{l}4.1 \\
\pm 1.2\end{array}$ & $\begin{array}{l}18.9 \\
\pm 0.3\end{array}$ & $\begin{array}{l}1.1 \\
\pm 1.3\end{array}$ & $\begin{array}{l}1.731 \\
\pm 0.157\end{array}$ & $\begin{array}{r}25.5 \\
\pm 0.9\end{array}$ & $\begin{array}{r}72.7 \\
\pm 2.7\end{array}$ & $\begin{array}{l}3.7 \\
\pm 0.6\end{array}$ & $\begin{array}{r}15.7 \\
\pm 1.7\end{array}$ & $\begin{array}{l}8.8 \\
\pm 0.1\end{array}$ \\
\hline \multirow[t]{4}{*}{ P.v. } & 33 & $\begin{array}{l}2.010 \\
\pm 0.410\end{array}$ & $\begin{array}{r}29.6 \\
\pm 4.4\end{array}$ & $\begin{array}{l}97.8 \\
\pm 12.2\end{array}$ & $\begin{array}{l}1.9 \\
\pm 0.0\end{array}$ & $\begin{array}{l}13.5 \\
\pm 2.2\end{array}$ & $\begin{array}{l}7.3 \\
\pm 2.3\end{array}$ & $\begin{array}{l}2.070 \\
\pm 0.419\end{array}$ & $\begin{array}{r}30.8 \\
\pm 3.2\end{array}$ & $\begin{array}{r}97.9 \\
\pm 3.9\end{array}$ & $\begin{array}{l}1.9 \\
\pm 0.3\end{array}$ & $\begin{array}{l}9.9 \\
\pm 0.9\end{array}$ & $\begin{array}{r}13.4 \\
\pm 1.4\end{array}$ \\
\hline & 37 & $\begin{array}{l}2.366 \\
\pm 0.441\end{array}$ & $\begin{array}{l}30.9 \\
\pm 0.9\end{array}$ & $\begin{array}{r}103.5 \\
\pm 6.4\end{array}$ & $\begin{array}{l}2.1 \\
\pm 0.3\end{array}$ & $\begin{array}{l}14.5 \\
\pm 0.0\end{array}$ & $\begin{array}{l}7.8 \\
\pm 2.1\end{array}$ & $\begin{array}{l}1.679 \\
\pm 0.503\end{array}$ & $\begin{array}{r}27.1 \\
\pm 2.7\end{array}$ & $\begin{array}{r}90.9 \\
\pm 9.5\end{array}$ & $\begin{array}{l}2.2 \\
\pm 0.1\end{array}$ & $\begin{array}{l}8.8 \\
\pm 1.6\end{array}$ & $\begin{array}{l}11.4 \\
\pm 3.0\end{array}$ \\
\hline & 41 & $\begin{array}{l}2.034 \\
\pm 0.488\end{array}$ & $\begin{array}{r}25.6 \\
\pm 2.4\end{array}$ & $\begin{array}{l}86.2 \\
\pm 4.7\end{array}$ & $\begin{array}{l}1.4 \\
\pm 0.1\end{array}$ & $\begin{array}{l}11.8 \\
\pm 0.4\end{array}$ & $\begin{array}{l}6.2 \\
\pm 1.7\end{array}$ & $\begin{array}{l}1.586 \\
\pm 0.508\end{array}$ & $\begin{array}{r}26.8 \\
\pm 1.7\end{array}$ & $\begin{array}{r}89.7 \\
\pm 2.3\end{array}$ & $\begin{array}{l}1.9 \\
\pm 0.3\end{array}$ & $\begin{array}{l}8.5 \\
\pm 0.4\end{array}$ & $\begin{array}{l}11.9 \\
\pm 0.1\end{array}$ \\
\hline & 45 & 2.095 & 26.8 & 88.3 & 3.4 & 11.0 & 8.6 & 1.456 & 23.9 & 78.4 & 2.2 & 7.4 & 10.7 \\
\hline
\end{tabular}




\begin{tabular}{|l|l|l|l|l|l|l|l|l|l|l|l} 
\pm 0.388 & \pm 5.1 & \pm 11.1 & \pm 2.1 & \pm 4.7 & \pm 0.5 & \pm 0.371 & \pm 5.1 & \pm 12.8 & \pm 0.5 & \pm 1.0 & \pm 1.3 \\
\hline
\end{tabular}


Table 5_Juneau et al.

Results of the 2 factor ANOVA procedure for the comparison of the parameters measured in Navicula phyllepta (N.p.), Biremis lucens (B.l.) and Plagiogrammopsis vanheurckii (P.v.) exposed to different salinities and lights. Code: white + n.s. (non significant): $\mathrm{p}>0.05$; light grey $+*: \mathrm{p}<0.05$; medium grey $+* *: \mathrm{p}<0.01$; dark grey $+* * *: \mathrm{p}$ $<0.001$; arrow up, increase of values; arrow down, decrease of values. The two factor ANOVA analysis was performed on data shown in Tables 3 and 4, Fig. 2 and 3.

\begin{tabular}{|c|c|c|c|c|}
\hline \multicolumn{5}{|l|}{ Salinity } \\
\hline & N.p. & B.1. & P.v. & \\
\hline $\mathrm{F}_{\mathrm{v}} / \mathrm{F}_{\mathrm{m}}$ & n.s. & n.s. & n.s. & \\
\hline ФPSII & n.s. & n.s. & n.s. & \\
\hline$\alpha$ & n.s. & n.s. & $*$ & $\downarrow$ \\
\hline $\mathrm{rETR}_{\mathrm{m}}$ & n.s. & $* \quad \downarrow$ & *** & $\uparrow$ \\
\hline$E_{k}$ & n.s. & $* \quad \downarrow$ & $* *$ & $\uparrow$ \\
\hline $\mathrm{NPQ}_{\mathrm{m}}$ & n.s. & n.s. & $*$ & $\downarrow$ \\
\hline DES & n.s. & n.s. & n.s. & \\
\hline DD & n.s. & n.s. & n.s. & \\
\hline DT & n.s. & n.s. & n.s. & \\
\hline Chl $a$ & n.s. & n.s. & n.s. & \\
\hline $\mathrm{Chl} c$ & n.s. & n.s. & n.s. & \\
\hline $\mathrm{Fx}$ & n.s. & n.s. & n.s. & \\
\hline B-car & n.s. & n.s. & n.s. & \\
\hline
\end{tabular}

\begin{tabular}{|c|c|c|c|c|}
\hline Light & & & & \\
\hline & N.p. & B.1. & P.v. & \\
\hline $\mathrm{F}_{\mathrm{v}} / \mathrm{F}_{\mathrm{m}}$ & $* * * \quad \downarrow$ & $* * * \quad \downarrow$ & $* * *$ & \\
\hline ФPSII & $* \quad \downarrow$ & $* * * \quad \downarrow$ & $*$ & $\downarrow$ \\
\hline$\alpha$ & n.s. & $* * * \quad \downarrow$ & ** & $v$ \\
\hline $\mathrm{rETR}_{\mathrm{m}}$ & n.s. & n.s. & n.s. & \\
\hline $\mathrm{E}_{\mathrm{k}}$ & n.s. & $\begin{array}{ll}* * & \uparrow\end{array}$ & * & $\uparrow$ \\
\hline $\mathrm{NPQ}_{\mathrm{m}}$ & $* * * \uparrow$ & $* * * \quad \uparrow$ & *** & $\uparrow$ \\
\hline DES & $* * * \quad \uparrow$ & $* * * \quad \uparrow$ & $* * *$ & $\uparrow$ \\
\hline DD & n.s. & $* * * \quad \downarrow$ & $* * *$ & $\downarrow$ \\
\hline DT & $* * * \quad \uparrow$ & $\begin{array}{ll}* * & \uparrow\end{array}$ & *** & $\uparrow$ \\
\hline Chl $a$ & *** & n.s. & n.s. & \\
\hline Chl $c$ & n.s. & n.s. & n.s. & \\
\hline Fx & n.s. & n.s. & n.s. & \\
\hline B-car & n.s. & n.s. & n.s. & \\
\hline
\end{tabular}

\begin{tabular}{|l|l|l|l|}
\hline \multicolumn{3}{|l|}{ Light x Salinity } \\
& N.p. & B.l. & P.v. \\
\hline $\mathrm{F}_{\mathrm{v}} / \mathrm{F}_{\mathrm{m}}$ & n.s. & n.s. & n.s. \\
$\Phi P S I I$ & n.s. & n.s. & n.s. \\
$\alpha$ & n.s. & n.s. & n.s. \\
rETR $_{\mathrm{m}}$ & n.s. & n.s. & n.s. \\
$\mathrm{E}_{\mathrm{k}}$ & n.s. & $*$ & n.s. \\
$\mathrm{NPQ}_{\mathrm{m}}$ & ** & n.s. & n.s. \\
$\mathrm{DES}$ & n.s. & n.s. & n.s. \\
$\mathrm{DD}$ & n.s. & n.s. & n.s. \\
$\mathrm{DT}$ & n.s. & n.s. & n.s. \\
$\mathrm{Chl} a$ & n.s. & n.s. & n.s. \\
Chl $c$ & n.s. & n.s. & n.s. \\
Fx & n.s. & n.s. & n.s. \\
$B-$ car & n.s. & n.s. & n.s. \\
\hline
\end{tabular}


Figure 1_Juneau et al.
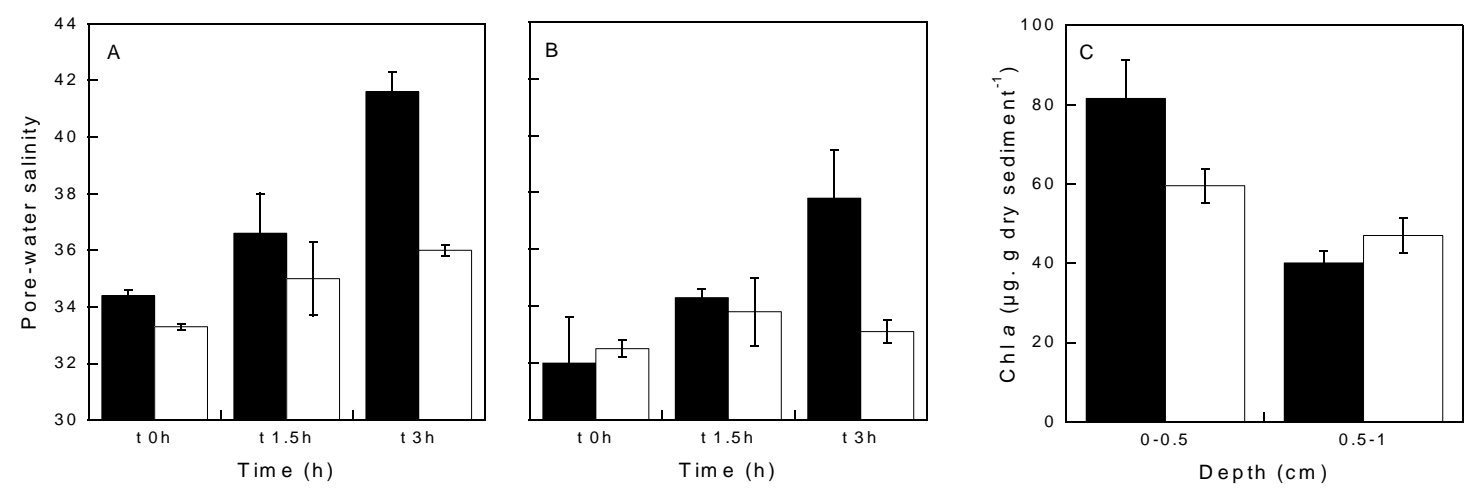
Figure 2_Juneau et al.

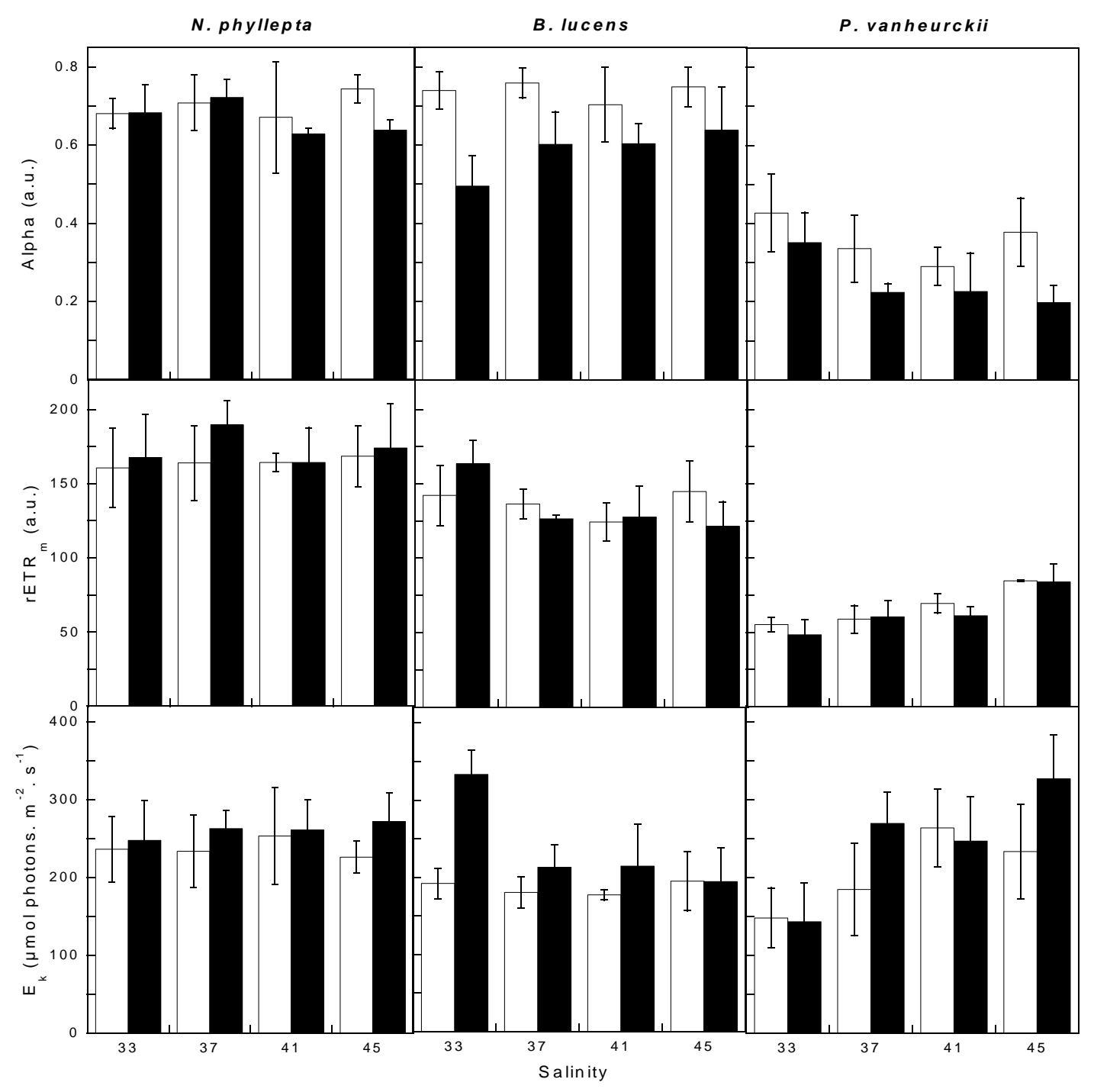


Figure 3_Juneau et al.
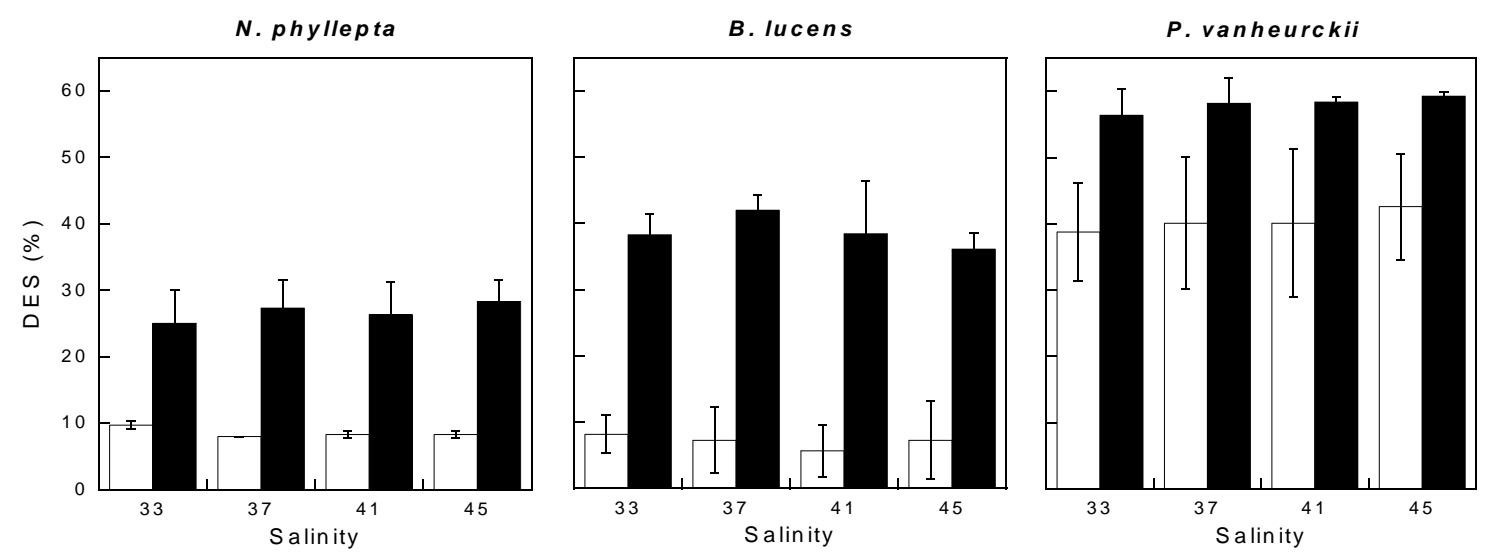